Canadian

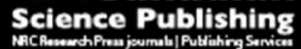

Canadian Journal of Physiology and Pharmacology Revue canadienne de physiologie et pharmacologie

\title{
The role of cancer stem cells in tumor heterogeneity and resistance to therapy
}

\begin{tabular}{|r|l|}
\hline Journal: & Canadian Journal of Physiology and Pharmacology \\
\hline Manuscript ID & cjpp-2016-0079.R1 \\
\hline Manuscript Type: & Review \\
\hline Date Submitted by the Author: & 08-Jun-2016 \\
\hline Kemplete List of Authors: & $\begin{array}{l}\text { Konrad, Christina; Garvan Institute of Medical Research, Cancer Research } \\
\text { Division \& Kinghorn Cancer Centre } \\
\text { Murali, Reshma; Rajiv Gandhi Center for Biotechnology, Cancer Research } \\
\text { Program } \\
\text { Varghese, Binitha; Rajiv Gandhi Centre for Biotechnology } \\
\text { Nair, Radhika; Rajiv Gandhi Centre for Biotechnology, }\end{array}$ \\
\hline Keyword: & $\begin{array}{l}\text { Cancer Stem Cells (CSCs), heterogeneity, therapy resistance, metastasis, } \\
\text { Tumorsphere assay }\end{array}$ \\
\hline &
\end{tabular}


1 The role of cancer stem cells in tumor heterogeneity and resistance to therapy

2

3 Christina Valbirk Konrad ${ }^{1}$, Reshma Murali ${ }^{2}$, Binitha Anu Varghese ${ }^{2}$, Radhika Nair ${ }^{2 *}$.

4

$5{ }^{1}$ Cancer Research Division \& Kinghorn Cancer Centre, Garvan Institute of Medical

6 Research, Darlinghurst, NSW 2010, Australia; ${ }^{2}$ Cancer Research Program , Rajiv Gandhi

7 Center for Biotechnology, Kerala, India.

8

$9 \quad{ }^{*}$ Corresponding author

10 Dr Radhika Nair

11 Rajiv Gandhi Center for Biotechnology

12 Kerala, India

13 radhikanair@rgcb.res.in

14 Phone: +91-471-2781251

15 Fax: +91-471-2346333

16 


\section{Abstract}

20

21 Cancer is a heterogenous disease displaying marked inter- and intra- tumoral diversity. The 22 existence of Cancer Stem Cells (CSCs) has been experimentally demonstrated in a number of 23 cancer types as a subpopulation of tumor cells which drives the tumorigenic and metastatic 24 properties of the entire cancer. Thus, eradication of the CSC population is critical for the complete ablation of a tumor. This is however confounded by the inherent resistance of CSCs to standard anti-cancer therapies, eventually leading to the outgrowth of resistant tumor cells and relapse in patients. The cellular mechanisms of therapy resistance in CSCs are ascribed to several factors including a state of quiescence, an enhanced DNA damage response and active repair mechanisms, up regulated expression of drug efflux transporters as well as the activation of pro-survival signaling pathways and inactivation of apoptotic signaling. Understanding the mechanisms underlying the acquisition of resistance to therapy may hold the key to targeting the CSC population.

\section{Keywords}

37 Cancer Stem Cells (CSCs), Heterogeneity, Therapy resistance, Metastasis, Tumorsphere assay. 
Introduction

42 Cancer poses a major global health problem as it is one of the leading causes of morbidity 43 worldwide and kills more than eight million men and women each year. An increasing insight 44 into the molecular and cellular mechanisms underlying tumorigenesis has emerged leading to 45 the development of targeted treatments. Although this has resulted in a significant decrease in 46 mortality rates for several cancer types, many cancers still lack effective targeted treatments 47 and thus rely on non-specific chemo- or radiotherapy that are associated with relapse and therapeutic resistance (Longo et al. 2007). An in depth understanding of the biology and molecular mechanisms driving tumor progression, metastasis, relapse and resistance to

50 therapy in cancer is therefore urgently required in order to enable effective therapies for 51 cancer patients.

\section{Inter- and intra- tumoral heterogeneity}

54 Cancer is known to be a heterogeneous disease displaying marked genetic and phenotypic variation not only between patients but also within the individual tumor (Bedard et al. 2013; Burrell et al. 2013; Polyak 2011). Inter- tumoral heterogeneity in tumors originating from

57 different tissues could result from variations in gene expression profiles and signaling 58 pathways of different cell types. In addition, diverse genetic events of oncogenic transformation and the interplay of each tumor with the surrounding microenvironment largely influence tumor progression, aggressiveness and the sensitivity of a tumor to therapy

61 (Junttila and de Sauvage 2013). This tumor heterogeneity poses a significant challenge to

62 effective cancer treatment as it may vary throughout disease progression, metastasis or drug 63 treatment due to changes in selection pressures and the microenvironmental niche. 
64 Two models have been proposed to explain tumor progression and heterogeneity, namely

65 "the clonal evolution model" in which tumor heterogeneity originates from the outgrowth of 66 sub-clones with an acquired selective advantage (Nowell 1976), and "the cancer stem cell

67 model" where tumor cells are hierarchically organized according to their tumorigenic 68 potential (Reya et al. 2001; Shackleton et al. 2009).

69 The clonal evolution model proposes that all cells within a tumor are biologically equivalent 70 and inherently possess the same tumorigenic potential (Nowell 1976). However, epigenetic modifications, acquired mutations and genetic instability associated with tumor progression leads to the formation of sub-clones, most of which decline due to a selective disadvantage. Occasionally a mutation confers an additional growth advantage with respect to the original tumor cells, leading to their selection and outgrowth as a dominant sub-population within the tumor. For example, an acquired mutation conferring drug resistance could explain relapse in patients due to the persistence and outgrowth of a resistant sub-clone.

On the other hand, the cancer stem cell model puts forward a hierarchical system in which tumor growth and progression are sustained by a distinct subpopulation of tumor cells with a stem-like phenotype, termed cancer stem cells (CSCs) (Reya et al. 2001). Key properties of CSCs are their ability to self-renew and multi-potent differentiation. This refers to the capacity of CSCs to divide symmetrically or asymmetrically (Morrison and Kimble 2006) to maintain a tumor-propagating subpopulation of tumor cells, while also giving rise to a heterogeneous population of more differentiated, fast dividing non-tumorigenic progenitor cells that make up the remaining tumor bulk mass.

Variation within a tumor could also be influenced by the interplay of the tumor cells with the extracellular environment which would include the immune system and other cells that make

87 up the surrounding matrix. While the clonal evolution and CSC models represent two extreme hypotheses for the generation of heterogeneity in cancer, they are not mutually 
89 exclusive models. It is not hard to imagine that a population of cells within the tumor (CSCs) 90 could be more susceptible to random genetic changes due to changes in DNA repair mechanisms, which could result in phenotypes advantageous to a cancer cell. Analysis of the mutational spectrum in solid tumors like breast cancer has clearly demonstrated the existence of sub-clones which could also interact with each other (Fillmore et al. 2010; Kandoth et al. 2013; Rajaram et al. 2015; X. Zhang et al. 2015). These findings have also been extended to the isolation of subclones with similar and different mutations in primary and metastatic tumors supporting a stochastic clonal evolution model (Ding et al. 2010; Vignot et al. 2013). A tumor could also follow a combination of the two models . For example, while colorectal cancers follow a CSC model, sequencing of tumors when serially passaged in mice also reveal new genetic variants that were not originally present in the patient (O'Brien et al. 2007; Ricci-Vitiani et al. 2007). While solid cancers like breast cancer demonstrate a clear hierarchical organization, the jury is still out in the case of leukemias and melanomas (Boiko et al. 2010; Quintana et al. 2010; Schatton et al. 2008). Researchers have further used single cell technology to demonstrate that metastasis is established by tumor cells with increased stem-like, mesenchymal and quiescence associated genes, which differentiate to form proliferative cells in advanced metastatic disease (Lawson et al. 2015).

Experimental testing of heterogeneity can be confounded by plasticity associated with CSCs, which refers to the ability of cells to transition through different phenotypic states. One definition of plasticity could be the ability of a cell to give rise to tumorigenic and nontumorigenic progeny. The distribution of the CSC population in tumors having a larger number of CSCs with the ability to differentiate into tumorigenic and non-tumorigenic 111 progeny would generate more aggressive tumors. This has important therapeutic 112 consequences where a drug targeting a particular cancer cell state would be rendered 113 ineffective if it has reverted to a drug resistant phenotype. One of the well studied 
114 phenomenon of plasticity deals with the transition between epithelial and mesenchymal states 115 in breast cancer (Gupta et al. 2011). Studies have demonstrated in breast cancer that CSCs are 116 capable of transitioning between epithelial and mesenchymal states via the process of EMT 117 (Epithelial-Mesenchymal-Transition) and MET (Mesenchymal-Epithelial-Transition). This 118 could potentially lead to the cancer being a constantly moving target. This is also true in 119 melanomas which show different tumor initiating ability based on reversible activation of the 120 histone demethylase JARID1B (Roesch et al. 2010). Plasticity is an important consideration 121 in the clinic as it has been demonstrated that changes in the cellular state could be responsible 122 for the acquisition of drug resistance (Sharma et al. 2010) which could be dependent on the 123 epigenetic status of a cell. It would be important to understand if the degree and the 124 proportion of cells exhibiting plasticity within a tumor are directly correlated to the 125 acquisition of drug resistance.

\section{Discovery of Cancer Stem Cells}

128 The existence of CSCs was initially alluded to in the $19^{\text {th }}$ century when histological similarities were noted between tumors and embryonic tissue (Sell 2004) and resulted in the "embryonal rest theory". This theory proposed that a small population of dormant embryonic stem cells remained within adult tissues as remnants from embryogenesis and could be activated by an unbalance in the tissue environment to cause cancer. Due to lack of experimental evidence to support this idea, the "embryonal rest theory" was abandoned for 134 half a century. The pioneering observation in the mid- $20^{\text {th }}$ century that teratocarcinomas, recognized as malignant structures arising from germ cells, were made up of not only an abnormal mixture of diverse types of mature, differentiated tissue but also of morphologically undifferentiated cells, suggesting their origin from tumorigenic stem cells. However, the first work to support the CSC model and evidence for the existence of CSCs was provided by 
139 Dick and colleagues in the hematopoietic research field (Lapidot et al. 1994). Utilizing the 140 observed similarity between tumors and embryonic tissue, they demonstrated the ability of a 141 rare subset of leukemic cells expressing the normal stem cell surface markers $\left(\mathrm{CD} 34^{+} / \mathrm{CD}^{-} 8^{-}\right)$ 142 to initiate tumors when transplanted into severe combined immunodeficient (SCID) mice. 143 The xenografted tumor cells expressing the stem cell surface markers could effectively 144 propagate and histologically recapitulate the heterogeneity of the original tumor with the 145 presence of both CSCs and more differentiated tumor cells. In contrast, the tumor cells 146 lacking expression of the stem cell surface markers did not have tumorigenic potential.

147 These early studies have since sparked enormous interest into CSC research. The first 148 identification of prospective CSCs in solid cancers was made in breast cancer (Al-Hajj et al. 149 2003). Using a cocktail of cell surface markers that included Lineage $/ \mathrm{CD} 44^{+} / \mathrm{CD} 24^{-/ \text {low }}$, they 150 demonstrated that this breast cancer cell subpopulation was significantly enriched for 151 tumorigenic potential, capacity of serial tumor propagation and the generation of a 152 heterogeneous population of tumor cells. This initial demonstration of prospective CSCs in breast cancer, led to the later discovery of CSCs in an assortment of solid cancers including brain, colon, pancreas, melanoma, ovary, prostate and skin cancers (Table 1).

\section{Tracking down Cancer Stem Cells}

157 To study the biology of CSCs and understand the mechanisms underlying their functional 158 phenotype with the aim of developing effective cancer treatments, an essential requirement is the ability to comprehensively and selectively isolate the CSC population from tumors. This has however proven to be technically challenging. The current CSC markers are either unable to selectively enrich for CSCs or only mark a small subset of the multiple CSC subpopulations within the individual tumors (Visvader and Lindeman 2012). Due to the difficulties associated with CSC markers and their specificity, CSCs are studied based on 
164 their functional phenotypes such as self-renewal, multipotency and tumorigenic potential.

165 Key functional assays to study the CSC phenotype include the in vitro tumorsphere assay and 166 in vivo limiting dilution transplantation assay.

167 The sphere assay is a well established in vitro method for assessing the self-renewal capacity 168 of a cell population in different model systems (Singec et al. 2006). Tumor cells are grown in 169 low adherent conditions in the absence of serum, which selects for the growth of 170 undifferentiated cells with high self-renewal capacity. Under these low-adherent and non171 differentiating conditions, CSCs are hypothesized to be able to form three-dimensional 172 tumorspheres containing stem-like cells and a heterogeneous population of progenitor cells 173 with the ability to differentiate into multiple cell types. The self-renewal capacity of a cell 174 population is assessed by the ability of the cells to form tumorspheres upon multiple passages 175 and is proportional to the number of spheres formed. As multipotency is another key capacity 176 of CSCs, this property is tested in the tumorsphere assay by exposure of the prospective 177 CSCs to differentiating conditions by the addition of serum to the culture medium. 178 Although the tumorsphere assay has been useful for studies of the self- renewal phenotype associated with CSCs, several limitations exist for this assay (Pastrana et al. 2011). A significant caveat of the tumorsphere assay is the tendency of cells to aggregate and the fusion of spheres even at low densities due to migration of non-adherent cells as well as 182 movement of the culture plates (Coles-Takabe et al. 2008). Due to migration of cells and 183 fusion of spheres, true clonality can in theory only be guaranteed by plating of a single cell per well. However, cell density also affects cell proliferation due to the requirement of cells for paracrine signals. In addition, the in vitro conditions of the tumorsphere assay do not completely recapitulate the complexity of the in vivo niche. While a cell line may show high self-renewal capacity and long-term passaging in the tumorsphere assay, the cells may not have the same self-renewal and tumor propagating capacity when exposed to in vivo 
conditions. Another important caveat of the tumorsphere assay that may obscure the studies of CSCs is its inability to detect quiescent cells. The results obtained from the tumorsphere assay should thus be validated by in vivo experiments showing the tumor propagating potential of the cells in order to draw firm inferences about the self-renewal potential of CSCs (Pastrana et al. 2011).

The gold standard in methods to identify CSCs is the in vivo limiting dilution assay in which the tumor cell population of interest is serially transplanted at increasing numbers into animal models, to assess the tumorigeneity and tumor propagating capacity of the cells ( $\mathrm{Hu}$ and Smyth 2009). To prove the presence of CSCs in the transplanted cell population, the prospective CSCs should demonstrate in vivo tumor propagating capacity upon serial passaging and the ability to reestablish the phenotypic heterogeneity present in the original tumor. In addition, the frequency of CSCs within the tumor cell population of interest can be deduced from the number of cells transplanted into the recipient mice that is required for tumor formation (Hu and Smyth 2009). CSC detection often utilizes a combination of approaches, such as isolation of different tumor populations using cell surface markers and FACS, followed by the validation of CSC phenotypes utilizing the tumorsphere or limiting dilution assay.

Although the limiting dilution assay serves as a valuable method for studying CSCs in vivo, several important caveats exist for this assay. The use of immune-compromised animal models does not accurately recapitulate the tumor environment and could largely impact the apparent frequency of tumorigenic CSCs (Quintana et al. 2008). Research by Quintana and colleagues using the limiting dilution assay demonstrated an increase in the frequency of tumor-propagating melanoma cells of several magnitudes when using a more immunecompromised animal model; 1 in 46,000 cells were tumorigenic when transplanted into immune-compromised NOD/SCID mice whereas this number increased to 1 in 9 when using 
214 the highly immune-deficient NOD/SCID interleukin-2 receptor gamma chain null

215 (IL2R $\gamma$ null) mouse model and addition of matrigel. This denotes a nearly 5000 fold increase

216 in tumor propagating capacity based on the immune status of the host. Moreover, the cross-

217 species biological differences in the growth microenvironment and the possible inability of

218 murine factors to engage human receptors could have an impact on the tumor forming ability

219 of the cells, and thus alter the apparent frequency of tumorigenic CSCs. These limitations

220 challenge the foundation of the xenotransplantation or limiting dilution assay by suggesting

221 that it may simply be identifying subpopulations of cells that are capable of surviving in the

222 immune-compromised mouse environment rather than identifying true CSCs.

223 Additional approaches have been used to identify and isolate prospective CSCs from different

224 model systems. Though lineage tracing was originally utilized in the developmental field, it is

225 emerging as a powerful tool to understand the evolution of tumors. Lineage tracing has led to

226 the successful identification of the Sox9 expressing hair follicle bulge stem cells (Nowak et

227 al. 2008), $\operatorname{Lgr}^{+}$epithelial stem cells in different tissues (Snippert et al. 2010), including the

228 intestine (Barker et al. 2007), stomach (Barker et al. 2010) and hair follicle (Jaks et al. 2008).

229 Combining tissue specific promoters with multi color reporters and live- cell imaging has

230 allowed scientists to trace the fate of specific cells within a tumor, their contribution to tumor

231 and metastatic growth as well resistance to drugs. Using the neural stem cell marker Nestin

232 tagged with GFP, Chen et al identified glioma stem cells and further went on to demonstrate

233 that the CSCs were resistant to chemotherapy (J. Chen et al. 2012). Another approach utilizes

234 the lineage specific Cre-recombinase system with a reporter gene, such as the enzyme $\beta$ -

235 galactosidase or a fluorescent protein. Driessens and colleagues went on to demonstrate that

236 beneign papillomas follow a hierarchical model (Driessens et al. 2012). They identified two

237 tumor populations in benign papilloma with a rarer fraction of the slower cycling, longer

238 lived stem-like cells giving rise to the majority of the cells in the tumor. Hans Clevers work 
239 has led the field with elegant multi-color lineage tracing experiments. The identification of 240 the $\operatorname{Lrg} 5^{+}$tumor cells as the cell of origin for intenstinal adenomas utilized the Cre-confetti 241 reporter system and supports the CSC model (Schepers et al. 2012). Interestingly, it has been 242 shown in a Wnt-dependent model of adenomas that $\mathrm{Lgr5}^{-}$cells can give rise to $\mathrm{Lgr}^{+}$cells 243 and form spheroids and tumors with the same efficiency as $\operatorname{Lgr} 5^{+}$cells. Intestinal carcinomas 244 can thus be driven by both $\operatorname{Lgr} 5^{+}$and $\operatorname{Lgr} 5^{-}$cells (Schwitalla et al. 2013). Hence we must 245 interpret the results from assays in the context of different cancers to understand which 246 cancers follow the clonal evolution, CSC or a mixture of both models.

247 In vitro assays have been developed to identify CSCs based on molecular characteristics. 248 These include the Aldefluor assay which measures expression of the enzyme aldehyde 249 dehydrogenase (ALDH) (Ginestier et al. 2007; S. Deng et al. 2010). Tumor cells with high expression of the ALDH enzyme are able to detoxify the cytotoxic aldehyde intermediates produced upon exposure to chemotherapy agents and hence confer resistance to anticancer therapies. ALDH is found to be upregulated by a wide range of CSCs, however it is not usually sufficient for CSC identification and isolation (de Beca et al. 2013; Keysar and Jimeno 2010; Ricardo et al. 2011). Studies have shown that $\mathrm{ALDH}^{+} \mathrm{CSC}$ are more likely to form colonies in soft agar, form tumorspheres in serum-free media and exhibit chemoresistance when compared to the $\mathrm{CD} 44^{+} / \mathrm{CD} 24^{-}$cells, as well as the inability of the $\mathrm{CD}^{+} 4^{+} / \mathrm{CD} 24^{-} / \mathrm{ALDH}^{-}$cells to form tumors at all (Ginestier et al. 2007; Tanei et al. 2009). Another popular method for the isolation of CSCs is the Hoechst stain exclusion assay which identifies CSCs based on their tendency to up regulate expression of ATP-binding cassette transporters ( $\mathrm{ABC}$ transporters), which are active drug efflux pumps shown to be implicated in resistance to different anticancer therapies (Seigel and Campbell 2004). The identification of a "side population" (SP) with high expression of the drug efflux transporters and thus low 
264 other cancer types. But this assay must also be used with caution as it has been demonstrated 265 that the SP cells isolated from glioblastoma multiforme brain tumors do not have self-renewal 266 or tumor initiating properties (Broadley et al. 2011). On the other hand, label retention assays 267 take advantage of the quiescent phenotype associated with a subset of CSCs, which due to 268 their quiescent, non-dividing state, would retain more of a nucleotide label such as tritiated 269 thymidine (Kuwahara et al. 2008). Another important technique used for CSC detection is 270 immunohistochemistry (IHC). IHC has been commonly used to detect putative CSC markers 271 like CD44, CD24 and ALDH in patient tissue sections and evaluate their correlation with 272 distinct histological types (Lingala et al. 2010; Martin and Jiang 2014). Unfortunately, most 273 of these assays do not specifically identify all CSC populations within a tumor as they are 274 based on one particular CSC phenotype. Due to the presence of a number of CSC populations 275 within a tumor, this often leads to the experimental set up failing to identify CSC subsets that 276 do not share that particular phenotype.

277 A combination of enrichment techniques utilizing CSC markers to isolate tumor cells, 278 followed by functional validation of the CSC phenotypes associated with the sorted 279 populations is currently the best method to identify and validate the putative CSC fraction 280 within a tumor.

\section{Clinical importance of CSCs}

283 Metastasis and tumor relapse are major causes underlying cancer-related deaths, and accumulating evidence point towards CSCs playing a critical role in this regard. A main cause of cancer relapse is attributed to the persistence of CSCs, which have been shown to possess an inherent resistance to standard anti-cancer therapies such as chemotherapy and radiation ( $\mathrm{Li}$ et al. 2008; Phillips et al. 2006). Standard therapies thus target the tumor bulk but fail to eradicate the resistant CSCs, which gives a possible explanation for the relapse 
observed in a major subset of patients undergoing standard treatments. Effective targeting of the CSC subpopulation is therefore essential for the complete eradication of a tumor and prevention of tumor relapse in patients.

However, accumulating evidence suggests that CSCs are not a fixed subset of a tumor but are able to convert between tumorigenic CSC states and more differentiated, non-CSC states (Gupta et al. 2011). This plasticity may be essential for tumor progression, as epithelial-tomesenchymal transition (EMT) and its reverse cellular process, mesenchymal-to-epithelial transition (MET), are key steps in tumor invasiveness and metastasis (Elshamy and Duhe 2013; Sampieri and Fodde 2012; Shiozawa et al. 2013). Studies have demonstrated the ability of the tumor microenvironment to induce EMT in differentiated cancer cells to confer a CSClike state with mesenchymal features greatly facilitating invasion and systemic dissemination from the primary tumor (Mani et al. 2008; Marjanovic et al. 2013). Oppositely, the disseminated tumor cells homing at distant organ sites may undergo MET and develop into metastatic lesions as a response to local stimulation from the microenvironment at the metastatic site. For example, TGF- $\beta$, which is recognized as an effective inducer of EMT, has been shown to efficiently promote the conversion of non-CSC basal breast cancer cells to confer a CSC state through the transcription factor ZEB1 (Chaffer et al. 2013).

In addition, heterogeneity within the CSC population of tumor cells may give rise to several distinct CSC subsets with diverse phenotypes or tumor propagating capacities. This may be regulated by cell-intrinsic factors or in response to distinct microenvironmental stimulation and largely impacts on the sensitivity of a tumor to therapy. Whereas one CSC population may show extensive self-renewal or proliferative capacity, another CSC subpopulation may be quiescent with the ability to drive tumor relapse upon activation years after anticancer therapy. Moreover, only a subset of CSCs may have the ability to undergo the complex metastatic process and colonize distinct microenvironmental niches. Diversity of CSC 
314 populations is aptly demonstrated by studies in which the transcription factor Id1 marks 315 glioblastoma stem cells (Anido et al. 2010). In these studies the $\operatorname{Id} 1^{\text {low }}$ tumor cells were reported to have greater tumorigenic potential than the Id $1^{\text {high }}$ subpopulation of glioblastoma

317 cells, which however were shown to have the greatest self-renewal capacity of the CSC population. A deeper understanding of the factors controlling or inducing the CSC state as well as finding a common denominator of the distinct subsets of CSCs are thus of great importance for the development of effective cancer treatments.

Genomic approaches to deconvoluting tumor heterogeneity have also given us insights into the evolution of cancers. Analysis of the genomic, transcriptomic and epigenetic states has revealed extensive heterogeneity in Acute Myeloid Leukemia (AML) (Walter et al. 2012), chronic lymphocytic leukaemia (CLL) (Schuh et al. 2012), breast cancer (Navin et al. 2011; Nik-Zainal et al. 2012; Shah et al. 2012), renal cell carcinoma (Xu et al. 2012) and pancreatic cancers (Campbell et al. 2010; Waddell et al. 2015). Due to the rapid advances in the field, we can now not only look at whole tumor populations, but at single cell resolution. Interestingly, a recent paper from Lawson et al, demonstrated a hierarchical model for the establishment of metastasis. Using a single cell approach, they conclusively show that metastasis is established by cells with increased stem-like, mesenchymal and quiescence associated genes, which differentiate to form proliferative cells in advanced metastatic analyze the molecular pathways using array and RNA-sequencing technology. A breast CSC signature was identified using ALDH1 as a prospective CSC marker in 33 cell lines. A 413gene expression profile was identified from the $\mathrm{ALDH}^{+} \mathrm{CSCs}$ and an association with the 
339 CSC assays as detailed in earlier sections. Further functional assays confirmed that IL-8 was 340 important for the self-renewal and metastatic phenotypes associated with CSCs (Charafe341 Jauffret et al. 2009; Singh et al. 2013). Another approach has used the better characterized 342 developmental counterpart of a cancer and extrapolated the signatures from pure stem cells to 343 understand the genes driving tumorigenesis. Merlos-Suarez and colleagues identified an 344 intestinal stem cell (ISC) signature using EphB2 and Lrg5 as markers of the ISC and found 345 that this was also predictive of relapse in colorectal cancer (Merlos-Suarez et al. 2011). A 346 similar strategy was adopted by Zhang and colleagues to demonstrate that the transcriptional 347 profile of basal epithelial cells in the prostate was associated with aggressive prostate cancer 348 (D. Zhang et al. 2016). CD44 has been used to isolate CSCs in breast cancer revealing a 31349 gene signature which is also predictive of distant metastasis in patients (de Jong et al. 2015; 350 Leth-Larsen et al. 2012; Linge et al. 2016). Continuous refinement of CSC markers with 351 isolation of pure populations is the need of the hour for the generation of clinically relevant 352 CSC gene signature sets.

\section{Resistance to anticancer therapy}

The mechanism of action of chemo- and radiation therapy has been intensely studied for decades. Chemotherapy covers cytotoxic chemical compounds that act by killing actively dividing cells in a non-specific manner by several distinct mechanisms such as stabilization of enzyme-DNA complexes, DNA fragmentation and inter- and intra-strand cross linking of the DNA, which interfere with cell division and results in the induction of apoptosis (Sarah and David 2008). Radiation therapy works by damaging the DNA of cancer cells by inducing single- or double-strand breaks (Lomax et al. 2013). This DNA damage is caused by either direct ionization of the molecular constituents of the DNA chain or indirectly by forming free radicals through ionization of water molecules that damage the DNA and results in 
364 potentially cytotoxic or mutagenic lesions. Cellular stress responses to DNA damage results

365 in cell cycle arrest and the activation of DNA repair mechanisms to protect genomic integrity.

366 However, upon irreversible DNA damage, cell death by apoptosis is induced in the damaged

367 cell.

368 Standard anticancer therapy thus aims to target the uncontrolled proliferative phenotype of 369 cancer cells. However, increasing insight into intra-tumoral heterogeneity and cellular 370 hierarchy indicates that standard anticancer treatments might miss the root cause of tumor 371 progression and metastasis, namely CSCs as described previously. Due to the inherent 372 persistence of therapy resistant CSCs, standard anticancer therapies such as chemotherapy 373 and radiation affects the tumor bulk but fail to eliminate the CSC population. Cancer patients 374 thus have a good initial response to therapy when targeting the tumor bulk, but a poor overall 375 survival due to outgrowth of the remaining chemo-resistant CSCs (Carey et al. 2007) 376 resulting in tumor relapse in patients. Therapy resistance is thus a major impediment to 377 successful treatment, and effective targeting of the CSC subpopulation is essential for the complete eradication of a tumor.

379 The cellular mechanisms of therapy resistance in CSCs have been extensively studied and ascribed to several factors including anti-apoptotic properties and activation of pro-survival signaling pathways as well as increased expression of drug efflux transporters with broad specificity that lower the intracellular drug concentration through active efflux mechanisms.

383 The resistance of CSCs to therapy is additionally thought to result from their capacity for active DNA-repair and the induction of a quiescent state characterizing a subset of the heterogeneous CSC population of tumor cells (Figure 1).

\section{Quiescence}

388 Resistance of CSCs to standard therapies is partly ascribed to the quiescence of a subset of 
389 CSCs, which refers to a non-dividing state in which the cells maintain the capacity to reenter 390 an active, proliferative cellular state. Standard treatments such as chemo- and radiation therapy predominantly act by targeting actively dividing cells. Thus, quiescence of CSCs poses an effective means of evading cancer treatments and conferring therapy resistance. Activation of CSCs from a quiescent state could then drive tumor relapse years after anticancer therapy. The acquisition of resistance to anticancer therapy in CSCs due to a quiescent state is supported by research in colorectal cancer by Touil et al (Touil et al. 2014). In this study, the fraction of cancer cells conferring resistance to 5-fluorouracil chemotherapy displayed a CSC phenotype based on markers, self-renewal and tumor propagating potential, and entered into a quiescent state upon exposure to the drug. Induction of quiescence in the chemo-resistant cancer cells upon exposure to 5-fluorouracil involved the activation of the cYes tyrosine kinase and its dissociation from the c-Yes/YAP complex, resulting in reduced nuclear levels of Yes-associated protein (YAP). This study suggests a mechanism by which the depletion of nuclear YAP, which is a transcriptional co-activator shown to be involved in stem cell self-renewal, arrests the cells in a non-dividing, quiescent state. Interestingly, in Alzheimer's disease, nuclear translocation of YAP has been reported to activate apoptosis related genes in response to accumulation of amyloid-beta-peptide in a p73 dependent mechanism (H. Zhang et al. 2011). Thus, the decrease in nuclear levels of YAP could be another way in which CSCs use a transcriptional co-activator to simultaneously impinge on the cell cycle and apoptotic pathways, and induce a state of quiescence. A recent study in glioblastomas further supports the hypothesis that CSCs utilize the induction of a quiescent state as a mechanism to acquire reduced sensitivity to standard therapies. By exposing

411 tumorspheres containing both quiescent cells (as marked by increased label retention) and 412 non-quiescent cells to chemotherapy, Campos et al reported higher frequencies of viable 
413 quiescent cancer cells than their non-quiescent counterparts after chemotherapy treatment

414 (Campos et al. 2014).

415 However, marked heterogeneity exists within the CSC subpopulation of tumor cells 416 displaying distinct molecular and functional phenotypes with only a subset of CSCs in the 417 state of quiescence. Research suggests that CSCs have the ability to convert between these 418 quiescent, slow-cycling and more active states, thus adding a further level of complexity 419 towards effective anticancer therapy.

Drug efflux transporters

422 An important factor contributing to therapy resistance in cancer patients is ascribed to the increased expression of drug efflux transporters in therapy resistant CSCs. These drug efflux transporters are mainly located in the cellular plasma membrane where they function normally to protect cells from harmful cytotoxic agents. Drug efflux transporters play an important role in protecting against cytotoxins and metabolic waste products especially in the blood brain barrier, liver, kidney and intestinal tissue (Gottesman et al. 2002).

428 In cancer, resistance of CSCs to therapy results in part from the up regulated expression of 429 the transporters, as increased drug efflux across the plasma membrane lowers intracellular 430 drug concentration (Gottesman et al. 2002). Due to their broad substrate specificity for 431 morphologically and functionally distinct compounds, the increased expression of the drug 432 efflux transporters may confer resistance to multiple anti-cancer drugs. Several drug efflux 433 transporters have been linked to therapy resistance in CSCs. The ATP-binding cassette 434 (ABC) family of transporter proteins, including multi-drug resistance protein 1 (MDR1, P435 glycoprotein or ABCB1), MDR-associated protein 1 (MRP1 or ABCC1) and breast cancer 436 resistance protein (BCRP or $\mathrm{ABCG}$ ) have been linked to therapy resistance (Z. Chen et al. 437 2016). These drug efflux transporters show extensive substrate specificity with the ability to 
438 promote efflux of several distinct compounds including chemotherapeutics. Substrate binding 439 to the active site of the drug efflux transporters causes an ATP-dependent conformational 440 change with the resulting release and thus efflux of the substrate to the extracellular space. 441 Targeting putative pathways that CSCs are dependent on for their survival upon exposure to 442 drugs might be a therapeutic alternative worth exploring (Pardal et al. 2003). One such 443 pathway that serves to protect the cells from external toxic agents or drugs is the over444 expression of $\mathrm{ABC}$ transporter proteins. Therefore, targeting the $\mathrm{ABC}$ transporter proteins 445 may be an alternative strategy to overcome therapy resistance. In combination with drugs 446 such as Topotecan, Afatinib (a tyrosine kinase inhibitor) was found to suppress the efflux 447 activity of only one member of the ABC subfamily (ABCG2) by inhibiting the ATPase 448 activity and down regulating the expression of the transporter (X. K. Wang et al. 2014). This 449 ultimately led to the accumulation of the drug in the breast cancer cells and reversal of the 450 chemoresistant phenotype. Studies in adenoid cystic carcinoma have implicated the T-box 451 transcription factor Brachyury in the mechanism by which CSCs acquire radiotherapy resistance (Kobayashi et al. 2014). Mechanistic studies demonstrated that knockdown of 453 Brachyury lead to a decrease in expression of ATP- binding cassette transporter genes. Re expression of transcription factors such a Brachyury could be used as a strategy to resensitize the cells to the effects of radiotherapy.

Active DNA repair

458 As standard anticancer treatments including chemotherapy or radiation act by inducing DNA damage such as single- and double-strand breaks, their effectiveness largely rely upon the 460 inadequate activity of DNA repair mechanisms in the cancer cells. Normally, DNA damage is 461 recognized and repaired by a cellular DNA damage response (DDR) that plays an important 462 role in maintaining genomic integrity and cellular function. Upon irreversible DNA damage, 
463 cellular apoptosis or an irreversible state of senescence is induced in order to prevent 464 abnormal growth and transformation of the damaged cell (Jeggo et al. 2016; Pearl et al. 465 2015). However, the DNA damage response that functions to protect genomic integrity and 466 normal cellular function is additionally exploited by CSCs for protection against the DNA 467 damaging effect of chemotherapy and radiation.

468 Damage to DNA causes a change in its spatial structure. Upon recognition of aberrant 469 structures in the DNA by the DDR, cell cycle checkpoints are activated and cell cycle arrest 470 is induced to ensure that the DNA damage is corrected before continuing cell division. The 471 main sensors of DNA damage and regulators of checkpoint control are the ATM (Ataxia 472 Telangiectasia mutated) and ATR (ATM and RAD3-related) protein kinases. Whereas ATM 473 primarily recognizes double-strand breaks and disruptions in the DNA chain (Bakkenist and 474 Kastan 2003), ATR responds to the presence of single-stranded DNA at stalled replication 475 forks. Upon recognition of these structures, ATM and ATR phosphorylate downstream 476 substrates in a signaling cascade ultimately leading to cell cycle arrest and recruitment of 477 DNA repair effectors, or the induction of apoptosis upon irreversible DNA damage. Among 478 the main substrates of ATM and ATR are CHK1 and CHK2. Phosphorylation of CHK1 and 479 CHK2 leads to activation of a number of key proteins such as p53, which plays a key role in 480 cell cycle arrest, DNA repair and initiation of apoptosis; and CDC25A which leads to cell 481 cycle arrest by degradation of G1/S transition activators. Interestingly, several studies have 482 observed an increased DDR response in the CSC population. A study by Bao et al. observed an enrichment of $\mathrm{CD}_{133^{+}}$glioma stem cells following exposure to ionizing radiation, thus indicating an inherent resistance of these cells to radiation compared to CD133- glioma cells 485 (Bao et al. 2006). This inherent resistance of the $\mathrm{CD}_{133^{+}}$glioma stem cells to radiation was 486 conferred through an enhanced DDR, as increased activation of DDR factors ATM, CHK1 487 and $\mathrm{CHK} 2$ was observed in the $\mathrm{CD}_{133^{+}}$glioma stem cells following radiation. Moreover, the 
488 observed resistance of the $\mathrm{CD}_{133^{+}}$glioma cells to radiation was reversed by inhibition of 489 CHK1 and CHK2 (which are DDR factors), further supporting the key role of an enhanced 490 DNA damage response and repair mechanisms in conferring resistance to therapy. This 491 mechanism is further supported by studies in colon and pancreatic cancers. Gallmeier et al 492 demonstrated that $\mathrm{CD}_{133^{+}}$colon CSCs were more resistant to Cisplatin than $\mathrm{CD}^{2} 3^{-} \mathrm{CSCs}$ 493 through the increased phosphorylation of CHK1 (Gallmeier et al. 2011). This protective 494 effect was reversed when the cells were treated with the CHK1 inhibiting agent SB218078. 495 Similarly, treatment of chemoresistant $\mathrm{CD} 24^{+} / \mathrm{CD}_{4} 4^{+} / \mathrm{ESA}^{+}$pancreatic $\mathrm{CSC}$ to $\mathrm{CHK} 1$ 496 inhibitors lead to resensitization to Gemcitabine (Venkatesha et al. 2012).

497 Cells have developed several repair mechanisms to account for the variety of damage 498 inflicted on their DNA. These repair mechanisms include the nucleotide excision repair 499 (NER), base excision repair (BER), mismatch repair (MMR), and the double-strand break 500 (DSB) repair including homologous end joining (HE) and non-homologous end-joining 501 (NHEJ). Several excision repair mechanisms exist to repair damage in a single DNA strand 502 by removing the damaged DNA region and correctly synthesizing the new strand using the 503 complementary strand as a template. These excision repair mechanisms includes BER, NER and MMR, which recognizes and corrects base changes in the DNA chain, nucleotide alterations normally caused by chemicals or radiation, and mismatch match errors arisen during replication, respectively. Mechanisms to repair double-strand breaks include NHEJ and HE. HE relies on the presence of a homologous sister chromatid and can thus only occur 508 after replication, while NHEJ directly joins the two ends of the double strand break and 509 therefore relies on the presence of complementary, compatible overhangs. However, due to 510 the lack of a normal DNA strand, there is more likelihood of errors like deletions being 511 introduced during repair of DSB. CSCs utilize a number of strategies to repair DNA damage 512 and allow them to survive in spite of the toxic insults caused by chemotherapy. Venere and 
513 colleagues (Venere et al. 2014) have demonstrated increased single stranded break (SSB)

514 repair in GICs through the PARP1 pathway. Blocking of PARP1 reversed this protective 515 effect and could be used in conjunction with other drugs to sensitize CSCs to the effects of 516 therapy. Further evidence comes from the increased expression of DNA repair genes like 517 PARP, ATM and BRCA1 through Progranulin in Glioblastoma human samples (Bandey et 518 al. 2015) as well as up regulation of DSB repair genes in CD133 ${ }^{+}$CSCs in lung carcinoma 519 (Desai et al. 2014). Increased DNA damage response and repair capacities in CSCs thus pose 520 an effective mechanism by which CSCs evade the damaging effect of anticancer treatments. 521 It must be emphasized that heterogeneity in the tumor population could lead to different 522 strategies being employed by CSCs to evade the cytotoxic effects of therapy with enhanced 523 DNA damage response just one weapon in their arsenal.

Defective apoptotic pathways and increased pro-survival signaling

526 Apoptosis functions in normal biology to remove damaged or abnormal cells. Apoptosis thus 527 provides an important barrier against cancer and is induced by cellular stress responses to 528 DNA damage or abnormal cellular processes. However, specific mutations enable some 529 tumor cells to escape apoptosis and confer a more malignant phenotype. As such, the 530 activation of pro-survival signaling pathways and inactivation of apoptotic signaling are 531 critical means by which CSCs may confer drug resistance and evade apoptosis induced by 532 cellular stress responses to DNA damage. The two main apoptotic signaling pathways are the 533 intrinsic pathway, which acts through intracellular death signals in response to cellular stress, 534 and the extrinsic pathway that acts through extracellular stimulation of pro-apoptotic cell 535 surface receptors. The intrinsic and extrinsic signaling pathways ultimately converge and 536 result in the same apoptotic process of cellular degradation (Hanahan and Weinberg 2000, 537 2011). 
538 The intrinsic apoptotic pathway is initiated in response to intracellular stress signaling which 539 causes the release of cytochrome $\mathrm{c}$ and Smac/DIABLO pro-apoptotic proteins from the 540 mitochondria. Whereas Smac/DIABLO promote apoptosis by impeding the function of 541 inhibitors of apoptosis proteins (IAPs), cytochrome c binds and activates apoptotic protease 542 activating factor 1 (Apaf-1) and procaspase-9 to form the apopsome. The apopsome functions 543 to cleave and activate executioner caspases that trigger the apoptotic process of cell 544 degradation. The intrinsic pathway is regulated through a balance in expression of pro545 apoptotic proteins such as Bax, Bak, Bad, Bid, Bim, Bik, Noxa and Puma relative to the 546 expression of pro-survival proteins including Bcl-2, Bcl-X $\mathrm{L}$, and Mcl1 (Ouyang et al. 2012).

547 DNA damage induced by anticancer therapy such as chemotherapy or radiation results in the 548 accumulation of the tumor suppressor protein p53 (Schmitt et al. 2002; Z. Wang and Sun 549 2010). High cellular levels of p53 indirectly cause the induction of apoptosis through up 550 regulated levels of the pro-apoptotic Bax and Bak proteins.

551 CSCs evade the damaging effect of anticancer therapy by enhanced DNA damage response 552 (DDR) and repair mechanisms and additionally confer resistance to anticancer therapy 553 through increased pro-survival signaling and inactivation of pro-apoptotic proteins (Pearl et 554 al. 2015). Cellular levels of pro-survival proteins Bcl-2 and Bcl- $\mathrm{X}_{\mathrm{L}}$ as well as several IAPs 555 were found to be significantly up regulated in chemo-resistant CD133 ${ }^{+}$glioma stem cells 556 compared to $\mathrm{CD} 133^{-}$glioma cells in a study by Liu et al., whereas the expression of pro557 apoptotic Bax was significantly decreased (G. Liu et al. 2006). In another study, the 558 inhibition of Bcl-2 anti-apoptotic activity resulted in activation of pro-apoptotic Bax and the 559 induction of apoptosis in glioblastoma cells (Tagscherer et al. 2008). Furthermore, the up 560 regulated expression of cell surface growth receptors such as HER2, FGF and EGF has been 561 shown to inhibit apoptosis in chemo-resistant CSCs through the down regulation of cellular 
562 levels of the pro-apoptotic Bad protein, thus inhibiting the intrinsic signaling pathway and 563 apoptosis (Economopoulou et al. 2012).

564 Increased pro-survival signaling and decreased expression of apoptotic genes would result in

565 CSCs acquiring resistance as they could overcome or counteract the death signals caused by 566 therapy-induced damage. The deregulated expression of the pro-survival and apoptotic 567 pathways may be caused by genomic instability and accumulating mutations associated with 568 tumor progression or as a consequence of the DNA damaging effect of standard anticancer 569 therapy. Mutations leading to deregulated expression of anti-apoptotic proteins such as Bcl-2 570 and Bcl-xl, inactivation of pro-apoptotic factors such as p53, Bax and Bak, or an increase in 571 pro survival signals such as Survivin and cFLIP could on their own or together cause 572 apoptotic dysregulation and confer a survival advantage on CSCs (Vidal et al. 2014). For 573 example, the anti-apoptotic cFLIP protein is found to be over expressed in colon, thyroid 574 cancers and melanoma (Dutton et al. 2006; Griffith et al. 1998; Ryu et al. 2001; Todaro et al. 575 2006). Interestingly, the $\mathrm{CD}_{133^{+}} \mathrm{CSC}$ fraction of a leukemia cell line were found to over 576 express cFLIP and protect cells from apoptosis. This could be reversed by depleting the cells 577 of cFLIP in siRNA knock down experiments, thus restoring the extrinsic apoptotic pathway 578 (Zobalova et al. 2008a; Zobalova et al. 2008b).

580 Caveats associated with CSC biology

581 Understanding the molecular circuitry of CSCs is critical for the design of new and improved 582 therapies against this sub-population of tumor cells. Isolation of CSCs from a heterogeneous 583 tumor mass to a high degree of purity has been a major stumbling block in the field (Visvader 584 and Lindeman 2012). This is evident from xenotransplantation assays in which the number of 585 CSCs identified in tumors is much lower than suggested by the markers, thus indicating lack 
586 of specificity of the markers used to identify CSCs. As elaborated in Table 1, the classical 587 CSC markers such as CD $44^{+} / \mathrm{CD} 24^{-/ \text {low }}$ only identify a fraction of the CSCs in the breast.

588 One of the major limitations in the CSC biology field are that the assays currently used to 589 identify this subpopulation of cells based on critical phenotypes such as self-renewal. As 590 discussed in detail in the previous section on tracking CSCs, the use of the tumorsphere or 591 limiting dilution assays in isolation does not efficiently identify all the CSC populations that 592 may exist in a tumor. While the in vivo recapitulation of an entire tumor from a single cell is 593 considered the gold standard for assessing CSC activity, unfortunately the use of immune 594 595 for the isolation and study of CSCs.

602

\section{Discussion}

604 Research over the past few decades has resulted in important breakthroughs in our 605 understanding of cancer and lead to the development of better therapeutic options for 606 patients. This has had a direct impact on better survival rates in many cancer types. But 607 unfortunately, effective targeted therapy is still lacking for some cancer types like pancreatic 608 cancer as well as metastatic cancer. These cancers still rely mainly on surgical intervention 609 and non-specific chemo- or radio-therapy that is largely ineffectual. 
610 The discovery of CSC populations in a number of cancers has confounded successful 611 treatment due to the inherent therapy resistant phenotype associated with CSCs. One of the 612 major hurdles in designing new therapies against CSCs is our inability to isolate CSCs to a 613 high degree of purity, as the current "gold standards" in the field do not accurately identify 614 the true CSC (Table 1). An alternative approach would be to use publically available data to 615 identify genes critical for CSC phenotypes like self-renewal and chemo-resistance. 616 Prospective CSC molecular markers can then be used to specifically and effectively isolate 617 CSCs from a tumor. Utilizing genomic approaches, the molecular circuitry of the CSCs can 618 be elucidated to build a CSC gene signature. This could further allow us to identify cell 619 surface molecules that mark the true CSCs. Refinement in the methodologies used currently 620 to identify CSCs based on phenotype is also essential. Combining assays that utilize in vitro 621 methods like FACS and the tumorsphere assay to enrich for CSCs, followed by in vivo testing 622 in animal models would allow for more accurate identification of this cell population. 623 Unfortunately, often the rarity of CSC population makes validation in patient samples with 624 associated clinical parameters like survival data implausible.

625 Since chemo- and radio- therapy mainly targets the rapidly dividing tumor population, it 626 implicitly means that the slowly dividing or quiescent CSCs will be spared, which would 627 ultimately re-grow to cause relapse in the patient (Hellman et al. 2008). CSCs utilize a 628 number of mechanisms to circumvent the deleterious effects and ultimately cell death caused 629 by chemo- and radio- therapy as shown in Figure 1.

630 Chemotherapy and targeted therapy have benefitted the management of many cancers. 631 Unfortunately, many patients develop or acquire resistance to current modes of treatment. 632 The contribution of CSCs and consequently intra-tumoral heterogeneity, to this phenomenon 633 of acquired resistance leading to increased cancer mortality is now an area of active 634 investigation (Vidal et al. 2014). Several studies support this hypothesis with work in the 
635 leukemia field once again leading the way. For example, CD34 ${ }^{+}$(a marker of CSCs in AML) 636 correlated with poor prognosis in AML patient cohorts after chemotherapy (van Rhenen et al. 637 2005). This is not surprising as AML CSCs have been experimentally shown to be resistant to 638 the standard cytotoxic therapy cytarabine and the $\mathrm{CD} 34^{+} \mathrm{CD} 38^{-}$cell population is enriched 639 after treatment and indicative of relapse in patients (Gerber et al. 2012). Studies from 640 carcinomas like breast, pancreatic and colorectal cancers have also lent credence to the 641 hypothesis that CSCs contribute to acquired resistance. Breast CSCs identified by $642 \mathrm{CD} 24^{+} / \mathrm{CD}_{4} 4^{-}$and $\mathrm{ALDH} 1$ have been found to be enriched in patient samples post treatment, 643 while $\mathrm{CD} 133^{+}$cells from patient samples were more resistant to 5-fluorouracil and oxaliplatin than CD133- cells (Todaro et al. 2007). The presence of therapy resistant CSCs in a tumor could provide an explanation for the phenomenon of acquired resistance. Adopting a two 646 pronged strategy which debulks the tumor and targets the CSC population might be more 647 effective in preventing relapse in patients.

648 One possible approach would be to target alternative pathways that are critical for CSC 649 phenotypes like self-renewal. This would include the Notch, Shh, Bmil and Wnt signaling 650 pathways (Borah et al. 2015). One important caveat of such an approach would be the side 651 effects of targeting pathways common to both normal stem cells and CSCs. This could be 652 overcome by specifically delivering the drugs to only the CSC population, thus preventing 653 deleterious effects on normal cells.

654 The use of targeted antibodies against specific surface molecules or receptors which are 655 unique to CSCs is another therapeutic option. Apoptosis is one of the important pathways that 656 CSCs subvert in order to increase their resistance to chemotherapy. An interesting approach 657 would involve the manipulation of expression of pro- and anti- apoptotic proteins like Bad 658 and BCL-2, which could tilt the balance towards programmed cell death and thus elimination 
659 of the CSC (Edinger and Thompson 2004). The potential side effects of such a therapeutic 660 strategy on normal cells in tissues must be considered before implementation in the clinic.

661 Another emerging consensus is that CSCs can exhibit plasticity with the ability to convert 662 between CSC and non-CSC states. It might therefore not be enough to only target one subset 663 of CSCs in order to eradicate a tumor. To effectively ablate CSCs and prevent tumor relapse, 664 a combination of CSC-specific therapies with current therapies targeting the tumor bulk will 665 be required.

666 The tumor microenvironment (TME) is another important consideration in devising new 667 therapies against CSCs. In a manner akin to the stem cell niche, it has been postulated that 668 these are anatomically unique regions within the tumor, consisting of different cell types that 669 contribute to the acquisition and maintenance of CSCs. The TME consists of a number of 670 different cell types like Cancer Associated Fibroblasts (CAFs), Mesenchymal Stem Cells 671 (MSCs) and inflammatory cells. The importance of the TME has been underscored in an 672 elegant study by Quintana and colleagues (Quintana et al. 2010) where the tumor initiating 673 frequency of melanoma cells varied significantly depending on the immune status of the 674 recipient host. Studies have started to tease apart how the CSC niche could support the 675 genesis of CSCs, aid in plasticity between non-CSC and CSC populations, in addition to 676 contributing to metastasis and chemoresistance (Oskarsson et al. 2014; Ye et al. 2014). This 677 process can be a two way street as demonstrated with breast CSCs which produce IL6, which 678 in turn attracts and activates MSCs to produce the CSC-supportive cytokine CXCL7 (S. Liu 679 et al. 2011). It naturally follows that the CSC niche could also play a role in the acquisition of 680 resistance to conventional therapies. A classic example would be the hypoxic 681 microenvironment within tumors which are has been found to increase CSC pathways by the 682 activation of TGF- $\beta$ and Wnt signaling pathways (Anido et al. 2010; Scheel et al. 2011). 683 Components of the tumor stroma could also act as a physical impediment for the access of 
684 drugs to tumor cells. More recently, new data has supported the notion that the TME may 685 help to promote the conversion of non-CSCs to CSCs via induction of the EMT pathway in 686 tumor cells by tumor associated macrophages (TAMs) (Bruna et al. 2012; Cabarcas et al. 687 2011). One of the more intriguing concepts has been the establishment of the pre-metastatic 688 niche by the release of exosomes containing functional proteins, mRNA and miRNA 689 (Castellana et al. 2009; Jung et al. 2009; Muralidharan-Chari et al. 2010). Understanding the 690 mechanisms by which the tumor microenviroment forms a supportive CSC niche could be a 691 potential therapeutic avenue to explore.

692

693 
694 Table 1. CSC markers in different organ systems. The discovery of CSCs in multiple 695 cancer types utilizing a combination of cell surface markers to determine the CSC frequency.

696

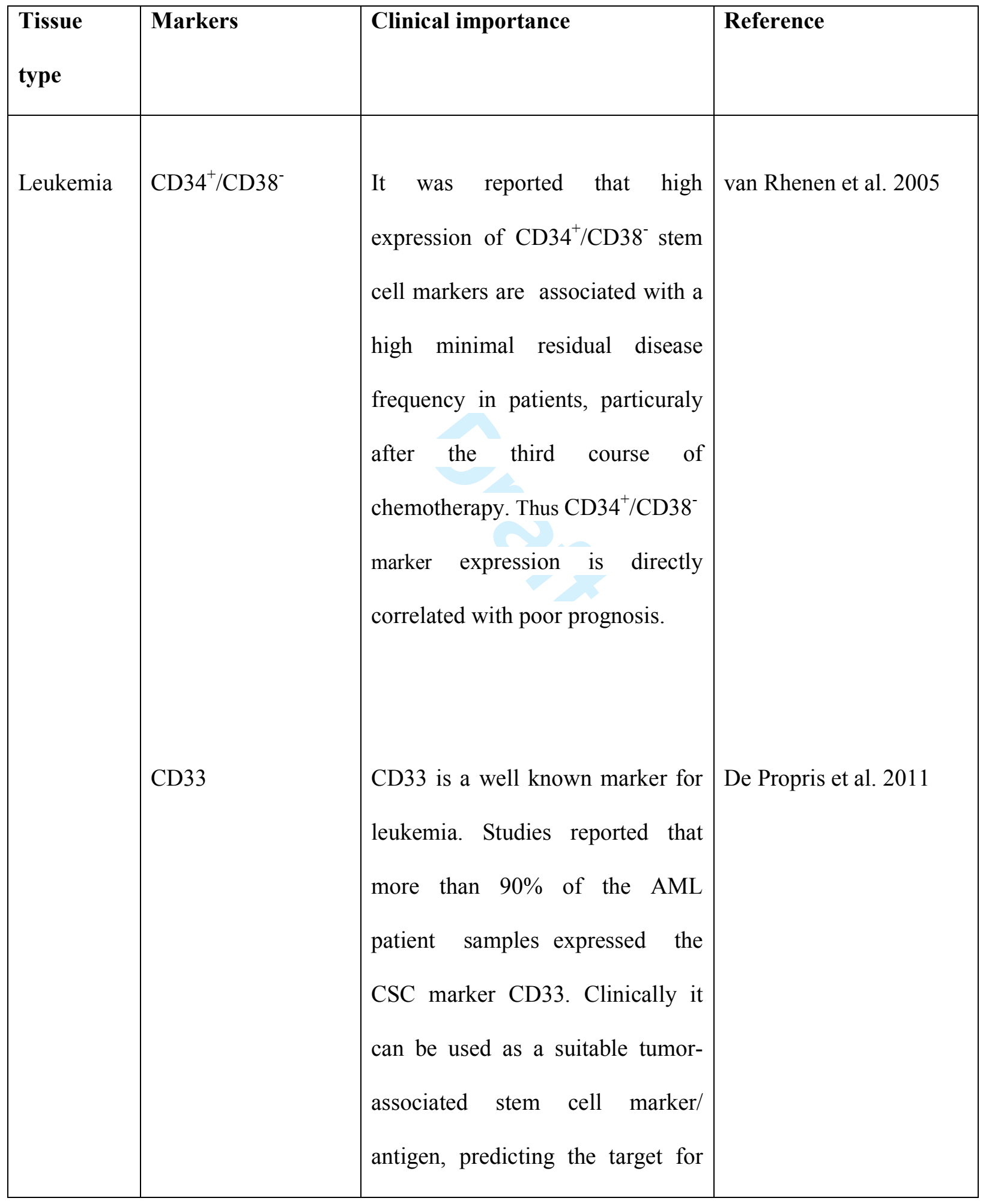




\begin{tabular}{|c|c|c|c|}
\hline & $\begin{array}{l}\text { BMI1 } \\
\text { c-kit } \\
\text { CD44 } \\
\text { GLI-1 }\end{array}$ & $\begin{array}{l}\text { antibody-based AML therapies. } \\
\text { Studies reported that CD123 is a } \\
\text { marker of leukemia-initiating } \\
\text { cells and a high percentage of } \\
\text { CD123 } / \mathrm{hMICL}^{+} \text {cells after } \\
\text { chemotherapy represent a strong } \\
\text { prognostic marker for relapse in } \\
\text { patients. } \\
\text { BMI1 is a marker for monitoring } \\
\text { the tumor progression and } \\
\text { invasion in AML patients, thus } \\
\text { predicting a poor prognosis in } \\
\text { patients with Chronic myeloid } \\
\text { leukemia. }\end{array}$ & $\begin{array}{l}\text { Saudy et al. } 2014 \\
\text { Wakita et al. } 2011 \\
\text { Zöller } 2015 \\
\text { B. Long et al. } 2016\end{array}$ \\
\hline Breast & $\begin{array}{l}\mathrm{CD} 44^{+} / \mathrm{CD} 24^{-/ \text {low }} \text { or } \\
\mathrm{ALDH} 1\end{array}$ & $\begin{array}{l}\text { High percentage of } \mathrm{CD} 44^{+} / \mathrm{CD} 24^{-} \\
/ \text {low and } \mathrm{ALDH}^{+} \text {markers were }\end{array}$ & Bane et al. 2013 \\
\hline
\end{tabular}




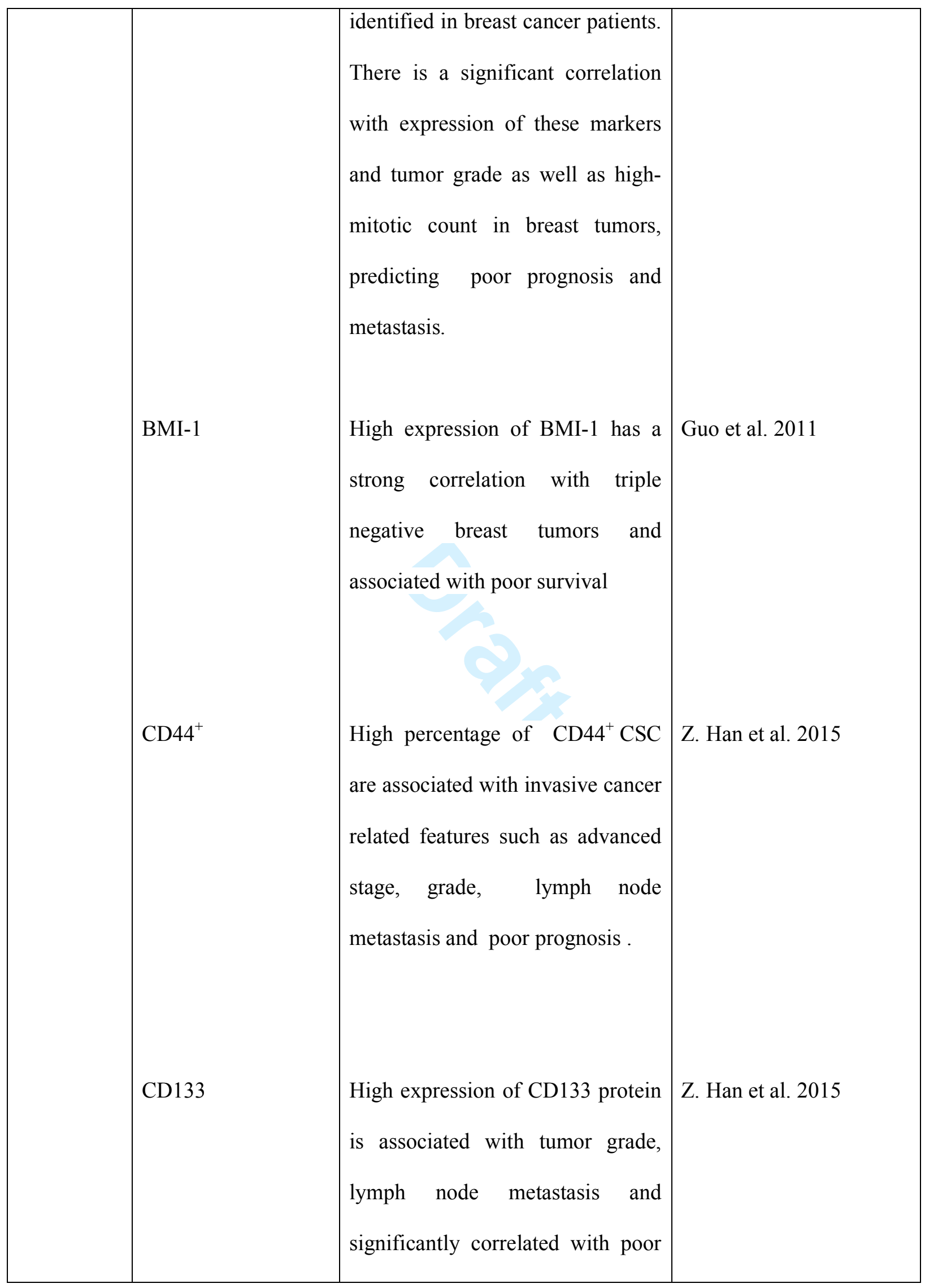




\begin{tabular}{|c|c|c|c|}
\hline & $\begin{array}{l}\text { CXCR4 } \\
\text { Beta1 integrin } \\
\text { LGR5 } \\
\text { CD90/Thy1 } \\
\text { Hedgehog-Gli }\end{array}$ & $\begin{array}{l}\text { prognosis of Infiltrating ductal } \\
\text { carcinoma patients. } \\
\text { Over expression of CXCR4 leads } \\
\text { to tumor growth, invasion, } \\
\text { angiogenesis, metastasis, relapse, } \\
\text { advanced tumor-node-metastasis } \\
\text { (TNM) stage and therapeutic } \\
\text { resistance, predicting poor } \\
\text { prognosis in cancer patients. }\end{array}$ & $\begin{array}{l}\text { Nisticò et al. } 2014 \\
\text { L. Yang et al. } 2015 \\
\text { X. Wang et al. } 2015 \\
\text { Peiris-Pages et al. } 2015\end{array}$ \\
\hline Brain & $\mathrm{CD}_{133^{+}} / \mathrm{Nestin}^{+}$ & $\begin{array}{l}\text { Low percentage of } \\
\mathrm{CD} 33^{+} / \mathrm{Nestin}^{+} \text {, markers are } \\
\text { associated with poor prognosis in } \\
\text { glioma patients. It was reported } \\
\text { that combined expression of } \\
\text { Nestin }^{+} / \mathrm{CD} 33^{+} \text {is an independent }\end{array}$ & M. Zhang et al. 2008 \\
\hline
\end{tabular}




\begin{tabular}{|c|c|c|c|}
\hline & GD3 $^{\text {high }}$ & $\begin{array}{l}\text { prognostic marker of gliomas. } \\
\text { High expression of GD3 correlates } \\
\text { with metastasis in brain tumors. } \\
\text { GD3 synthase is involved in the } \\
\text { characteristics of CSCs through } \\
\text { the c-MET signaling pathway. } \\
\text { Immunohistochemical analysis of } \\
\text { high-grade gliomas from clinical } \\
\text { samples revealed expression of } \\
\text { of tumor vasculatures. } \\
\text { role in the differentiation of } \\
\text { endial cells via the generation } \\
\text { andicant }\end{array}$ & Yeh et al. 2016 \\
\hline $\begin{array}{l}\text { Colorectal } \\
\text { cancer }\end{array}$ & $\mathrm{CD}_{133^{+}}$ & $\begin{array}{l}\text { High percentage of the } \mathrm{CD} 133^{+} \\
\text {marker is associated with poor } \\
\text { prognosis, recurrence, metastasis } \\
\text { and chemotherapy resistance } \\
\text { in patients. }\end{array}$ & $\begin{array}{l}\text { Ren et al. } 2013 \\
\text { B. B. Wang et al. } 2016\end{array}$ \\
\hline
\end{tabular}




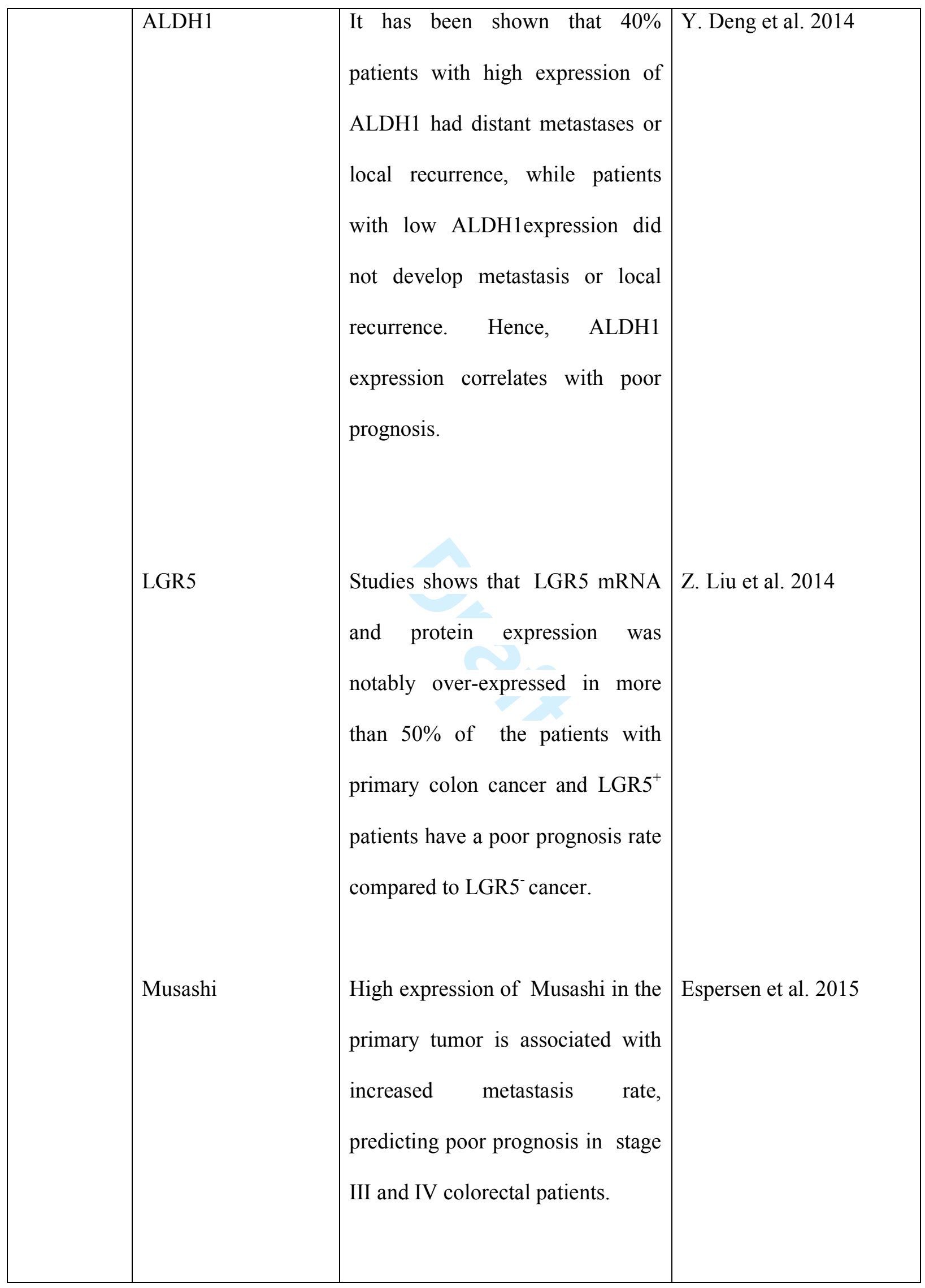




\begin{tabular}{|c|c|c|c|}
\hline & $\begin{array}{l}\mathrm{CD} 24^{+} / \mathrm{CD} 44^{+} \\
\mathrm{CD} 166\end{array}$ & & $\begin{array}{l}\text { D. A. N. Liu et al. } 2014 \\
\text { Shafaei et al. } 2013\end{array}$ \\
\hline \multirow[t]{3}{*}{$\begin{array}{l}\text { Pancreatic } \\
\text { cancer }\end{array}$} & $\begin{array}{l}\mathrm{CD} 24^{+} / \mathrm{CD} 44^{+} / \\
\mathrm{EpCAM}^{+}\end{array}$ & $\begin{array}{l}\text { Studies reported that } \mathrm{CD}^{+} 4^{+} \\
/ \mathrm{CD} 24^{+} / \mathrm{EpCAM}^{+} \text {stem cells are } \\
\text { associated with high proliferative } \\
\text { potential in clinical samples. High } \\
\text { percentage of } \mathrm{CD} 44^{+} \text {and } \mathrm{CD} 24^{+} \text {is } \\
\text { associated with } \\
\text { development, initiation, and } \\
\text { metastasis in pancreatic cancer } \\
\text { patients. }\end{array}$ & Ohara et al. 2013 \\
\hline & Nestin & $\begin{array}{l}\text { Nestin, a CSC marker plays an } \\
\text { important roles in pancreatic } \\
\text { cancer cell migration, invasion and } \\
\text { metastasis by selectively changing } \\
\text { the oxpression } \\
\text { actin/cytoskeleton and cell } \\
\text { adhesion molecules, predicting a } \\
\text { therapeutic target in PDAC. }\end{array}$ & Matsuda et al. 2011 \\
\hline & ALDH1A1 & ALDH1A1 expression & Kahlert et al. 2011 \\
\hline
\end{tabular}




\begin{tabular}{|c|c|c|c|}
\hline & $\begin{array}{l}\text { CD24 } \\
\text { ABCG-2 } \\
\text { ESA }{ }^{+} \\
\text {c-Met } \\
\text { CXCR4 } \\
\text { Nodal-Activin }\end{array}$ & $\begin{array}{l}\text { associated with tumour stage and } \\
\text { low expression of ALDH1A1 } \\
\text { significantly reduced survival in } \\
\text { ALDH1A1 }{ }^{\text {low }} \text { patients. }\end{array}$ & $\begin{array}{l}\text { Elkord 2012 } \\
\text { F. Wang et al. } 2010 \\
\text { Wei et al. } 2011 \\
\text { Fotovati et al. } 2011 \\
\text { Billadeau et al. } 2006 \\
\text { Lonardo et al. } 2011\end{array}$ \\
\hline Melanoma & CD271 & $\begin{array}{l}\text { High expression of } \mathrm{ABCB}^{+} \text {cells } \\
\text { are significantly associated with } \\
\text { with increased risk of metastatsis } \\
\text { and poor prognosis in melanoma } \\
\text { patients especially in smokers. } \\
\text { High expression of the CD271 cell } \\
\text { marker is present in the tumour- } \\
\text { initiating cell population, and }\end{array}$ & Boiko et al. 2010 \\
\hline
\end{tabular}




\begin{tabular}{|c|c|c|c|}
\hline & $\begin{array}{l}\mathrm{ALDH}^{+} \\
\mathrm{CD} 20^{+}\end{array}$ & $\begin{array}{l}\text { associated with high metastatic } \\
\text { burden and poor prognosis in } \\
\text { melanoma patients. } \\
\text { High expression of CD133/ } \\
\text { Nestin are associated with } \\
\text { advanced disease stage and } \\
\text { metastatic skin tumors. Thus } \\
\text { predicting a potential therapeutic } \\
\text { targets for malignant tumors of the } \\
\text { skin. }\end{array}$ & $\begin{array}{l}\text { Luo et al. } 2013 \\
\text { Pinc et al. } 2012\end{array}$ \\
\hline $\begin{array}{l}\text { Ovarian } \\
\text { cancer }\end{array}$ & $\mathrm{CD}_{4} 4^{+} / \mathrm{CD} 117^{+}$ & $\begin{array}{l}\text { Overexpression of } \mathrm{CD}^{+} 4^{+} \\
/ \mathrm{CD} 117^{+} \text {is associated with tumor } \\
\text { recurrence, metastasis and drug } \\
\text { resistance in ovarian cancer } \\
\text { patients. } \\
\text { In epithelial ovarian carcinoma } \\
\text { patients, increased cytoplasmic }\end{array}$ & $\begin{array}{l}\text { Kristiansen et al. } 2002 \\
\text { Burgos-Ojeda et al. 2015; }\end{array}$ \\
\hline
\end{tabular}




\begin{tabular}{|c|c|c|c|}
\hline & CD133 ${ }^{+}$ & $\begin{array}{l}\text { expression of CD24 is associated } \\
\text { with shortened survival. } \\
\text { High number of } \mathrm{CD} 133^{+} \text {cells in } \\
\text { ovarian primary tumors is } \\
\text { associated with self-renewal, } \\
\text { multi-differentiation and tumor } \\
\text { initiation capacities in patients }\end{array}$ & H. Long et al. 2015 \\
\hline $\begin{array}{l}\text { Prostate } \\
\text { cancer }\end{array}$ & 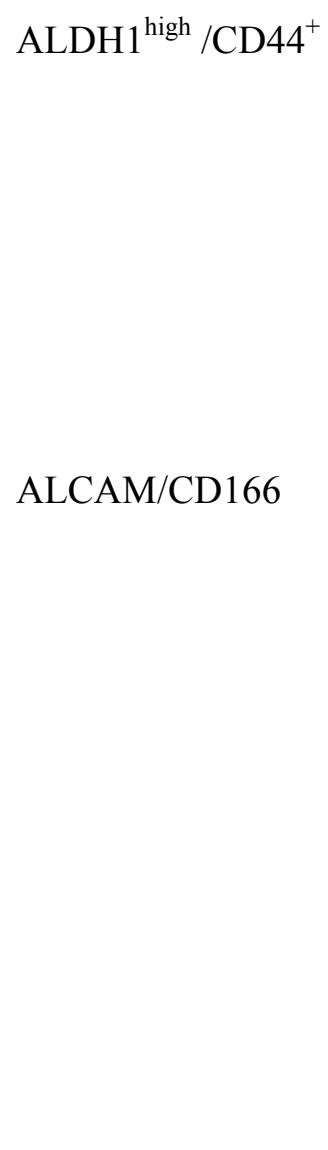 & $\begin{array}{l}\text { Prostate CSC markers ALDH } 1^{\text {high }} \\
\text { /CD44 }{ }^{+} \text {cells exhibit a higher } \\
\text { proliferative and metastatic } \\
\text { capacity in patients. } \\
\text { High } \\
\text { ALCAM/CD166 in prostate cancer } \\
\text { patients are associated bone } \\
\text { metastases and promote survival } \\
\text { and proliferation of prostate cancer } \\
\text { cells in the } \\
\text { microenvironment, predicting poor } \\
\text { prognosis in patients. }\end{array}$ & Hansen et al. 2014 \\
\hline & $\begin{array}{l}\text { ABCG2 } \\
\text { CD105 }\end{array}$ & & $\begin{array}{l}\text { Guzel et al. } 2014 \\
\text { Fujita et al. 2009; }\end{array}$ \\
\hline
\end{tabular}




\begin{tabular}{|c|c|c|c|}
\hline & $\begin{array}{l}\text { CD166 } \\
\text { Beta1 integrin } \\
\text { Trop2 } \\
\text { CD133 }\end{array}$ & & $\begin{array}{l}\text { Miyata et al. } 2015 \\
\text { Jiao et al. } 2012 \\
\text { Trerotola et al. } 2013 \\
\text { Trerotola et al. } 2012 \\
\text { Vander Griend et al. } \\
2008\end{array}$ \\
\hline $\begin{array}{l}\text { Liver } \\
\text { cancer }\end{array}$ & CD13 & 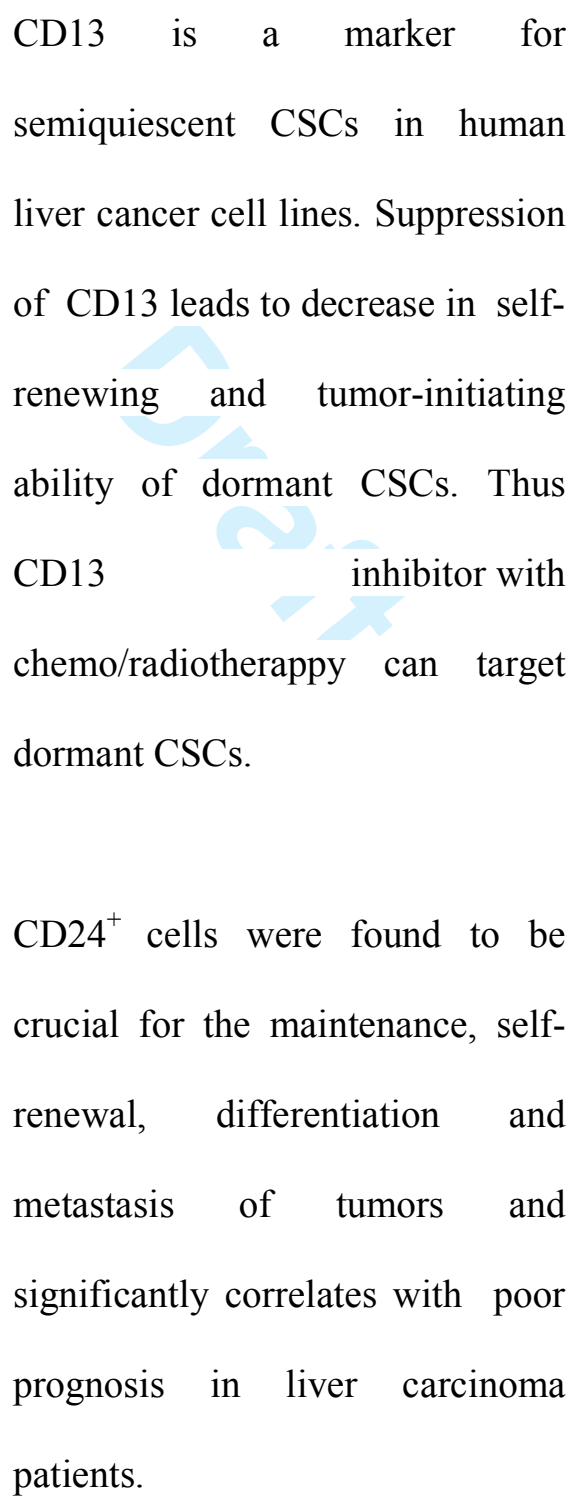 & Haraguchi et al. 2010 \\
\hline
\end{tabular}




\begin{tabular}{|c|c|c|c|}
\hline & CD90 & $\begin{array}{l}\text { Human liver cancer samples } \\
\text { showed that CD } 133^{+} / \mathrm{CD} 44^{+} \text {tumor } \\
\text { cells was associated with portal } \\
\text { vein metastasis and hematogenous } \\
\text { metastasis in liver cancer patients } \\
\text { CD90 expression in liver } \\
\text { carcinoma is associated with } \\
\text { increment in tumor growth and } \\
\text { decreased survival rate. } \\
\text { It was reported that CD133 liver } \\
\text { cancer cells promote angiogenesis, } \\
\text { tumorigenesis and self-renewal } \\
\text { through the IL- } 8 \text { signaling cascade } \\
\text { in cancer patients and predict } \\
\text { poorosis. }\end{array}$ & Z. F. Yang et al. 2008 \\
\hline Lung & ALDH1 & $\begin{array}{l}\text { Patients with ALDH1-positive } \\
\text { lung cancer had poor prognosis } \\
\text { whereas non-small cell lung } \\
\text { cancer patients with high } \\
\text { expression of ALDH1 have better } \\
\text { prognosis and lower recurrence } \\
\text { rates. Thus the effect of ALDH1 }\end{array}$ & Huo et al. 2015 \\
\hline
\end{tabular}




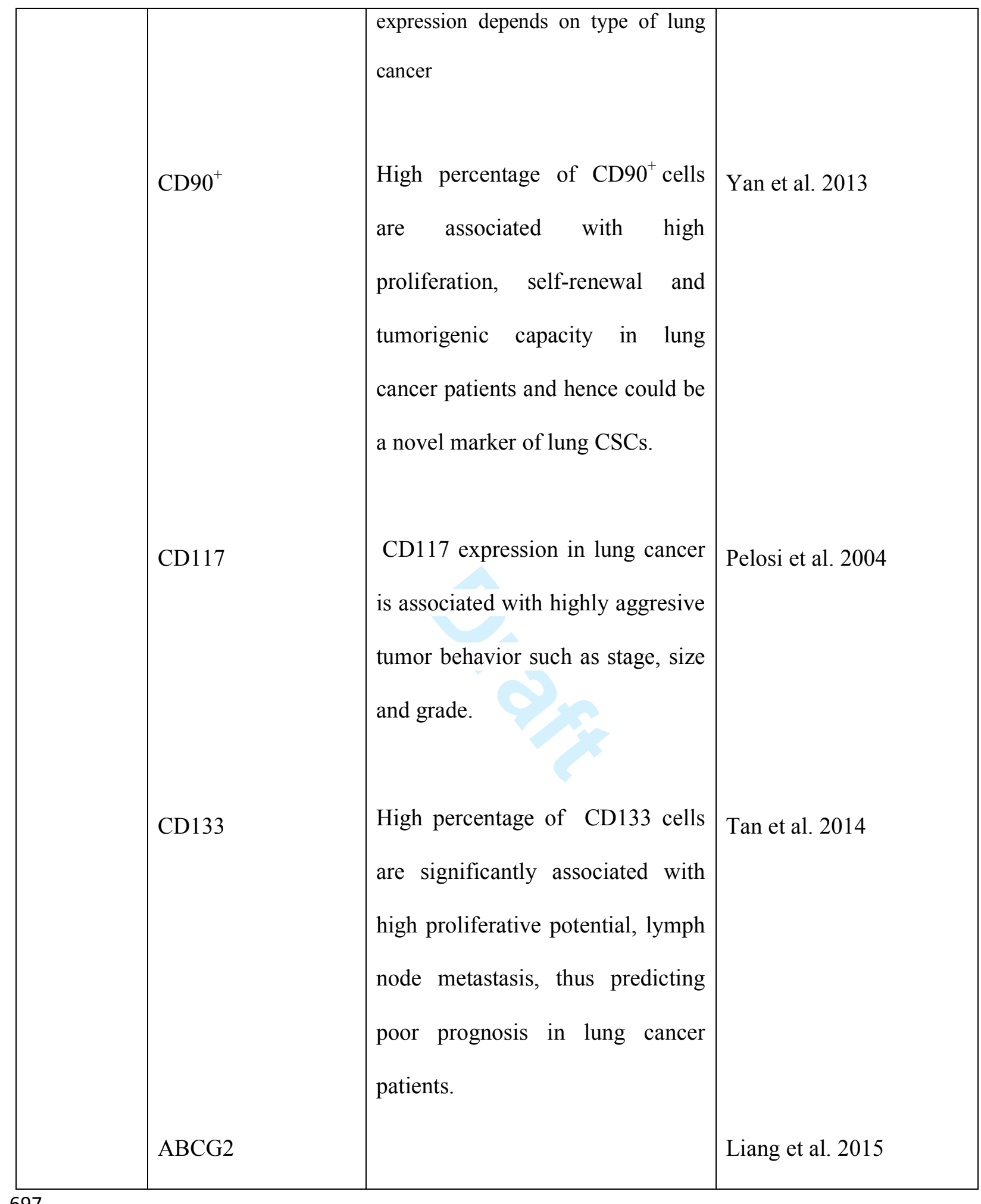

698

699 
700

701

702

703

704

705

706

707

708

709

710

711

712

713

714

715

716

717

718

719

720

721

722

723

724

725

726

727

728

729

730

731

732

733

734

735

736

737

738

739

740

741

742

743

744

745

746

747

748

\section{References}

Al-Hajj, M., Wicha, M. S., Benito-Hernandez, A., Morrison, S. J., and Clarke, M. F. 2003. Prospective identification of tumorigenic breast cancer cells. Proc. Natl. Acad. Sci. U.S.A. 100(7): 3983-3988.

Anido, J., Saez-Borderias, A., Gonzalez-Junca, A., Rodon, L., Folch, G., Carmona, M. A., et al. 2010. TGF-beta Receptor Inhibitors Target the CD44(high)/Id1(high) Glioma-Initiating Cell Population in Human Glioblastoma. Cancer Cell, 18(6): 655-668.

Bakkenist, C. J., and Kastan, M. B. 2003. DNA damage activates ATM through intermolecular autophosphorylation and dimer dissociation. Nature, 421(6922): 499-506.

Bandey, I., Chiou, S. H., Huang, A. P., Tsai, J. C., and Tu, P. H. 2015. Progranulin promotes Temozolomide resistance of glioblastoma by orchestrating DNA repair and tumor stemness. Oncogene, 34(14): 1853-1864.

Bane, A., Viloria-Petit, A., Pinnaduwage, D., Mulligan, A. M., O'Malley, F. P., and Andrulis, I. L. 2013. Clinical-pathologic significance of cancer stem cell marker expression in familial breast cancers. Breast Cancer Res. Treat. 140(1): 195-205.

Bao, S., Wu, Q., McLendon, R. E., Hao, Y., Shi, Q., Hjelmeland, A. B., et al. 2006. Glioma stem cells promote radioresistance by preferential activation of the DNA damage response. Nature, $\mathbf{4 4 4}(\mathbf{7 1 2 0})$ : 756-760.

Barker, N., Huch, M., Kujala, P., van de Wetering, M., Snippert, H. J., van Es, J. H., et al. 2010. Lgr5(+ve) stem cells drive self-renewal in the stomach and build long-lived gastric units in vitro. Cell Stem Cell, 6(1): 25-36.

Barker, N., van Es, J. H., Kuipers, J., Kujala, P., van den Born, M., Cozijnsen, M., et al. 2007. Identification of stem cells in small intestine and colon by marker gene Lgr5. Nature, 449(7165): 1003-1007.

Bedard, P. L., Hansen, A. R., Ratain, M. J., and Siu, L. L. 2013. Tumour heterogeneity in the clinic. Nature, 501(7467): 355-364.

Billadeau, D. D., Chatterjee, S., Bramati, P., Sreekumar, R., Shah, V., Hedin, K., et al. 2006. Characterization of the CXCR4 signaling in pancreatic cancer cells. Int. J. Gastrointest. Cancer, 37(4): 110-119.

Boiko, A. D., Razorenova, O. V., van de Rijn, M., Swetter, S. M., Johnson, D. L., Ly, D. P., et al. 2010. Human melanoma-initiating cells express neural crest nerve growth factor receptor CD271. Nature, 466(7302): 133-137.

Borah, A., Raveendran, S., Rochani, A., Maekawa, T., and Kumar, D. S. 2015. Targeting self-renewal pathways in cancer stem cells: clinical implications for cancer therapy. Oncogenesis, 4: e177.

Broadley, K. W., Hunn, M. K., Farrand, K. J., Price, K. M., Grasso, C., Miller, R. J., et al. 2011. Side population is not necessary or sufficient for a cancer stem cell phenotype in glioblastoma multiforme. Stem Cells, 29(3): 452-461. 
Bruna, A., Greenwood, W., Le Quesne, J., Teschendorff, A., Miranda-Saavedra, D., Rueda, O. M., et al. 2012. TGFbeta induces the formation of tumour-initiating cells in claudinlow breast cancer. Nat. Commun. 3: 1055.

Burgos-Ojeda, D., Wu, R., McLean, K., Chen, Y. C., Talpaz, M., Yoon, E., et al. 2015. CD24+ Ovarian Cancer Cells Are Enriched for Cancer-Initiating Cells and Dependent on JAK2 Signaling for Growth and Metastasis. Mol. Cancer Ther. 14(7): 1717-1727.

Burrell, R. A., McGranahan, N., Bartek, J., and Swanton, C. 2013. The causes and consequences of genetic heterogeneity in cancer evolution. Nature, 501(7467): 338-345.

Cabarcas, S. M., Mathews, L. A., and Farrar, W. L. 2011. The cancer stem cell niche--there goes the neighborhood? Int. J. Cancer, 129(10): 2315-2327.

Campbell, P. J., Yachida, S., Mudie, L. J., Stephens, P. J., Pleasance, E. D., Stebbings, L. A., et al. 2010. The patterns and dynamics of genomic instability in metastatic pancreatic cancer. Nature, 467(7319): 1109-1113.

Campos, B., Gal, Z., Baader, A., Schneider, T., Sliwinski, C., Gassel, K., et al. 2014. Aberrant selfrenewal and quiescence contribute to the aggressiveness of glioblastoma. J. Pathol. 234(1): 23-33.

Carey, L. A., Dees, E. C., Sawyer, L., Gatti, L., Moore, D. T., Collichio, F., et al. 2007. The triple negative paradox: primary tumor chemosensitivity of breast cancer subtypes. Clin. Cancer Res. 13(8): 23292334.

Castellana, D., Zobairi, F., Martinez, M. C., Panaro, M. A., Mitolo, V., Freyssinet, J. M., et al. 2009. Membrane microvesicles as actors in the establishment of a favorable prostatic tumoral niche: a role for activated fibroblasts and CX3CL1-CX3CR1 axis. Cancer Res. 69(3): 785-793.

Chaffer, C. L., Marjanovic, N. D., Lee, T., Bell, G., Kleer, C. G., Reinhardt, F., et al. 2013. Poised chromatin at the ZEB1 promoter enables breast cancer cell plasticity and enhances tumorigenicity. Cell, 154(1): 61-74.

Charafe-Jauffret, E., Ginestier, C., lovino, F., Wicinski, J., Cervera, N., Finetti, P., et al. 2009. Breast cancer cell lines contain functional cancer stem cells with metastatic capacity and a distinct molecular signature. Cancer Res. 69(4): 1302-1313.

Chatterjee, S., Azad, B. B., and Nimmagadda, S. 2014. The Intricate Role of CXCR4 in Cancer. Adv. Cancer Res. 124: 31-82.

Chen, J., Li, Y., Yu, T.-S., McKay, R. M., Burns, D. K., Kernie, S. G., et al. 2012. A restricted cell population propagates glioblastoma growth after chemotherapy. Nature, 488(7412): 522-526.

Chen, Z., Shi, T., Zhang, L., Zhu, P., Deng, M., Huang, C., et al. 2016. Mammalian drug efflux transporters of the ATP binding cassette (ABC) family in multidrug resistance: A review of the past decade. Cancer Lett. 370(1): 153-164.

Coles-Takabe, B. L., Brain, I., Purpura, K. A., Karpowicz, P., Zandstra, P. W., Morshead, C. M., et al. 2008. Don't look: growing clonal versus nonclonal neural stem cell colonies. Stem Cells, 26(11): 2938-2944. 
de Beca, F. F., Caetano, P., Gerhard, R., Alvarenga, C. A., Gomes, M., Paredes, J., et al. 2013. Cancer stem cells markers CD44, CD24 and ALDH1 in breast cancer special histological types. J. Clin. Pathol. 66(3): 187-191.

de Jong, M. C., Ten Hoeve, J. J., Grenman, R., Wessels, L. F., Kerkhoven, R., Te Riele, H., et al. 2015. Pretreatment microRNA Expression Impacting on Epithelial-to-Mesenchymal Transition Predicts Intrinsic Radiosensitivity in Head and Neck Cancer Cell Lines and Patients. Clin. Cancer Res. 21(24): 5630-5638.

De Propris, M. S., Raponi, S., Diverio, D., Milani, M. L., Meloni, G., Falini, B., et al. 2011. High CD33 expression levels in acute myeloid leukemia cells carrying the nucleophosmin (NPM1) mutation. Haematologica, 96(10): 1548-1551.

Deng, S., Yang, X., Lassus, H., Liang, S., Kaur, S., Ye, Q., et al. 2010. Distinct expression levels and patterns of stem cell marker, aldehyde dehydrogenase isoform 1 (ALDH1), in human epithelial cancers. PLoS One, 5(4): e10277.

Deng, Y., Zhou, J., Fang, L., Cai, Y., Ke, J., Xie, X., et al. 2014. ALDH1 is an independent prognostic factor for patients with stages II-III rectal cancer after receiving radiochemotherapy. Br. J. Cancer, 110(2): 430-434.

Desai, A., Webb, B., and Gerson, S. L. 2014. CD133+ cells contribute to radioresistance via altered regulation of DNA repair genes in human lung cancer cells. Radiother. Oncol. 110(3): 538-545.

Ding, L., Ellis, M. J., Li, S., Larson, D. E., Chen, K., Wallis, J. W., et al. 2010. Genome remodelling in a basal-like breast cancer metastasis and xenograft. Nature, 464(7291): 999-1005.

Driessens, G., Beck, B., Caauwe, A., Simons, B. D., and Blanpain, C. 2012. Defining the mode of tumour growth by clonal analysis. Nature, 488(7412): 527-530.

Dutton, A., Young, L. S. and Murray, P. G. 2006. The role of cellular FLICE inhibitory protein (c-FLIP) in the pathogenesis and treatment of cancer. Expert Opin. Ther. Targets, 10(1): 27-35.

Economopoulou, P., Kaklamani, V. G., and Siziopikou, K. 2012. The role of cancer stem cells in breast cancer initiation and progression: potential cancer stem cell-directed therapies. Oncologist, 17(11): 1394-1401.

Edinger, A. L., and Thompson, C. B. 2004. Death by design: apoptosis, necrosis and autophagy. Curr. Opin. Cell Biol. 16(6): 663-669.

Elkord, A. J. a. E. 2012. Significance of CD44 and CD24 as Cancer Stem Cell Markers: An Enduring Ambiguity. Clin. Dev. Immunol. 2012: 11.

Elshamy, W. M., and Duhe, R. J. 2013. Overview: cellular plasticity, cancer stem cells and metastasis. Cancer Lett. 341(1): 2-8.

Espersen, M. L., Olsen, J., Linnemann, D., Hogdall, E., and Troelsen, J. T. 2015. Clinical implications of intestinal stem cell markers in colorectal cancer. Clin. Colorectal Cancer, 14(2): 63-71. 
848 Fillmore, C. M., Gupta, P. B., Rudnick, J. A., Caballero, S., Keller, P. J., Lander, E. S., et al. 2010. 849 Estrogen expands breast cancer stem-like cells through paracrine FGF/Tbx3 signaling. Proc. Natl. 850 Acad. Sci. U.S.A. 107(50): 21737-21742.

Fotovati, A., Abu-Ali, S., Wang, P. S., Deleyrolle, L. P., Lee, C., Triscott, J., et al. 2011. YB-1 bridges neural stem cells and brain tumor-initiating cells via its roles in differentiation and cell growth. Cancer Res. 71(16): 5569-5578.

Fujita, K., Ewing, C. M., Chan, D. Y., Mangold, L. A., Partin, A. W., Isaacs, W. B., et al. 2009. Endoglin (CD105) as a urinary and serum marker of prostate cancer. Int. J. Cancer, 124(3): 664-669.

Gallmeier, E., Hermann, P. C., Mueller, M. T., Machado, J. G., Ziesch, A., De Toni, E. N., et al. 2011. Inhibition of ataxia telangiectasia- and Rad3-related function abrogates the in vitro and in vivo tumorigenicity of human colon cancer cells through depletion of the CD133(+) tumor-initiating cell fraction. Stem Cells, 29(3): 418-429.

Gao, M. Q., Choi, Y. P., Kang, S., Youn, J. H., and Cho, N. H. 2010. CD24+ cells from hierarchically organized ovarian cancer are enriched in cancer stem cells. Oncogene, 29(18): 2672-2680.

Gerber, J. M., Smith, B. D., Ngwang, B., Zhang, H., Vala, M. S., Morsberger, L., et al. 2012. A clinically relevant population of leukemic CD34(+)CD38(-) cells in acute myeloid leukemia. Blood, 119(15): 3571-3577.

Ginestier, C., Hur, M. H., Charafe-Jauffret, E., Monville, F., Dutcher, J., Brown, M., et al. 2007. ALDH1 is a marker of normal and malignant human mammary stem cells and a predictor of poor clinical outcome. Cell Stem Cell, 1(5): 555-567.

Gottesman, M. M., Fojo, T., and Bates, S. E. 2002. Multidrug resistance in cancer: role of ATPdependent transporters. Nat. Rev. Cancer, 2(1): 48-58.

Griffith, T. S., Chin, W. A., Jackson, G. C., Lynch, D. H., and Kubin, M. Z. 1998. Intracellular regulation of TRAIL-induced apoptosis in human melanoma cells. J. Immunol. 161(6): 2833-2840.

Guo, B. H., Feng, Y., Zhang, R., Xu, L. H., Li, M. Z., Kung, H. F., et al. 2011. Bmi-1 promotes invasion and metastasis, and its elevated expression is correlated with an advanced stage of breast cancer. Mol. Cancer, 10(1): 10.

Gupta, P. B., Fillmore, C. M., Jiang, G., Shapira, S. D., Tao, K., Kuperwasser, C., et al. 2011. Stochastic state transitions give rise to phenotypic equilibrium in populations of cancer cells. Cell, 146(4): 633644.

Guzel, E., Karatas, O. F., Duz, M. B., Solak, M., Ittmann, M., and Ozen, M. 2014. Differential expression of stem cell markers and ABCG2 in recurrent prostate cancer. Prostate, 74(15): 14981505.

Han, S., Guo, J., Liu, Y., Zhang, Z., He, Q., Li, P., et al. 2015. Knock out CD44 in reprogrammed liver cancer cell C3A increases CSCs stemness and promotes differentiation. Oncotarget, 6(42): 4445244465. 
Han, Z., Chen, Z., Zheng, R., Cheng, Z., Gong, X., and Wang, D. 2015. Clinicopathological significance of CD133 and CD44 expression in infiltrating ductal carcinoma and their relationship to angiogenesis. World J. Surg. Oncol. 13: 56.

Hanahan, D., and Weinberg, R. A. 2000. The hallmarks of cancer. Cell, 100(1): 57-70.

Hanahan, D., and Weinberg, R. A. 2011. Hallmarks of cancer: the next generation. Cell, 144(5): 646674.

Hansen, A. G., Arnold, S. A., Jiang, M., Palmer, T. D., Ketova, T., Merkel, A., et al. 2014. ALCAM/CD166 is a TGF-beta-responsive marker and functional regulator of prostate cancer metastasis to bone. Cancer Res. 74(5): 1404-1415.

Haraguchi, N., Ishii, H., Mimori, K., Tanaka, F., Ohkuma, M., Kim, H. M., et al. 2010. CD13 is a therapeutic target in human liver cancer stem cells. J. Clin. Invest. 120(9): 3326-3339.

He, J., Liu, Y., Zhu, T., Zhu, J., Dimeco, F., Vescovi, A. L., et al. 2012. CD90 is identified as a candidate marker for cancer stem cells in primary high-grade gliomas using tissue microarrays. Mol. Cell Proteomics, 11(6): M111.010744.

Hellman, S., Botnick, L., and Mauch, P. 2008. Stem-cell biology and cancer therapy: the more things change. J. Clin. Oncol. 26(6): 821-822.

Hu, Y., and Smyth, G. K. 2009. ELDA: extreme limiting dilution analysis for comparing depleted and enriched populations in stem cell and other assays. J. Immunol. Methods, 347(1-2): 70-78.

Huo, W., Du, M., Pan, X., Zhu, X., and Li, Z. 2015. Prognostic value of ALDH1 expression in lung cancer: a meta-analysis. Int. J. Clin. Exp. Med. 8(2): 2045-2051.

Jaks, V., Barker, N., Kasper, M., van Es, J. H., Snippert, H. J., Clevers, H., et al. 2008. Lgr5 marks cycling, yet long-lived, hair follicle stem cells. Nat. Genet. 40(11): 1291-1299.

Jeggo, P. A., Pearl, L. H., and Carr, A. M. 2016. DNA repair, genome stability and cancer: a historical perspective. Nat. Rev. Cancer, 16(1): 35-42.

Jiao, J., Hindoyan, A., Wang, S., Tran, L. M., Goldstein, A. S., Lawson, D., et al. 2012. Identification of CD166 as a surface marker for enriching prostate stem/progenitor and cancer initiating cells. PLoS One, 7(8): e42564.

Jung, T., Castellana, D., Klingbeil, P., Cuesta Hernandez, I., Vitacolonna, M., Orlicky, D. J., et al. 2009. CD44v6 dependence of premetastatic niche preparation by exosomes. Neoplasia, 11(10): 1093-1105.

Junttila, M. R., and de Sauvage, F. J. 2013. Influence of tumour micro-environment heterogeneity on therapeutic response. Nature, 501(7467): 346-354.

Kahlert, C., Bergmann, F., Beck, J., Welsch, T., Mogler, C., Herpel, E., et al. 2011. Low expression of aldehyde dehydrogenase $1 \mathrm{~A} 1$ (ALDH1A1) is a prognostic marker for poor survival in pancreatic cancer. BMC Cancer, 11: 275.

Kandoth, C., McLellan, M. D., Vandin, F., Ye, K., Niu, B., Lu, C., et al. 2013. Mutational landscape and significance across 12 major cancer types. Nature, 502(7471): 333-339. 
948 Keysar, S. B., and Jimeno, A. 2010. More than markers: biological significance of cancer stem cell949 defining molecules. Mol. Cancer Ther. 9(9): 2450-2457.

950
Kobayashi, Y., Sugiura, T., Imajyo, I., Shimoda, M., Ishii, K., Akimoto, N., et al. 2014. Knockdown of the T-box transcription factor Brachyury increases sensitivity of adenoid cystic carcinoma cells to chemotherapy and radiation in vitro: implications for a new therapeutic principle. Int. J. Oncol. 44(4): 1107-1117.

Kristiansen, G., Denkert, C., Schluns, K., Dahl, E., Pilarsky, C., and Hauptmann, S. 2002. CD24 is expressed in ovarian cancer and is a new independent prognostic marker of patient survival. Am. J. Pathol. 161(4): 1215-1221.

Kuwahara, R., Kofman, A. V., Landis, C. S., Swenson, E. S., Barendswaard, E., and Theise, N. D. 2008. The hepatic stem cell niche: identification by label-retaining cell assay. Hepatology, 47(6): 19942002.

Lapidot, T., Sirard, C., Vormoor, J., Murdoch, B., Hoang, T., Caceres-Cortes, J., et al. 1994. A cell initiating human acute myeloid leukaemia after transplantation into SCID mice. Nature, 367(6464): 645-648.

Lawson, D. A., Bhakta, N. R., Kessenbrock, K., Prummel, K. D., Yu, Y., Takai, K., et al. 2015. Single-cell analysis reveals a stem-cell program in human metastatic breast cancer cells. Nature, 526(7571): 131-135.

Lee, N., Barthel, S. R., and Schatton, T. 2014. Melanoma Stem Cells and Metastasis: Mimicking Hematopoietic Cell Trafficking? Lab. Invest. 94(1): 13-30.

Lee, T. K., Castilho, A., Cheung, V. C., Tang, K. H., Ma, S., and Ng, I. O. 2011. CD24(+) liver tumorinitiating cells drive self-renewal and tumor initiation through STAT3-mediated NANOG regulation. Cell Stem Cell, 9(1): 50-63.

Leth-Larsen, R., Terp, M. G., Christensen, A. G., Elias, D., Kühlwein, T., Jensen, O. N., et al. 2012. Functional Heterogeneity within the CD44 High Human Breast Cancer Stem Cell-Like Compartment Reveals a Gene Signature Predictive of Distant Metastasis. Mol. Med. 18(1): 1109-1121.

Li, X., Lewis, M. T., Huang, J., Gutierrez, C., Osborne, C. K., Wu, M. F., et al. 2008. Intrinsic resistance of tumorigenic breast cancer cells to chemotherapy. J. Natl. Cancer Inst. 100(9): 672-679.

Liang, S.-C., Yang, C.-Y., Tseng, J.-Y., Wang, H.-L., Tung, C.-Y., Liu, H.-W., et al. 2015. ABCG2 Localizes to the Nucleus and Modulates CDH1 Expression in Lung Cancer Cells. Neoplasia (New York, N.Y.), 17(3): 265-278.

Lingala, S., Cui, Y. Y., Chen, X., Ruebner, B. H., Qian, X. F., Zern, M. A., et al. 2010. Immunohistochemical staining of cancer stem cell markers in hepatocellular carcinoma. Exp. Mol. Pathol. 89(1): 27-35.

Linge, A., Lock, S., Gudziol, V., Nowak, A., Lohaus, F., von Neubeck, C., et al. 2016. Low Cancer Stem Cell Marker Expression and Low Hypoxia Identify Good Prognosis Subgroups in HPV(-) HNSCC after Postoperative Radiochemotherapy: A Multicenter Study of the DKTK-ROG. Clin. Cancer Res. 22(11): 2639-49. 
999

1000

1001

1002

1003

1004

1005

1006

1007

1008

1009

1010

1011

1012

1013

1014

1015

1016

1017

1018

1019

1020

1021

1022

1023

1024

1025

1026

1027

1028

1029

1030

1031

1032

1033

1034

1035

1036

1037

1038

1039

1040

1041

1042

1043

1044

1045

1046

1047

1048

1049

Liu, D. A. N., Sun, J., Zhu, J., Zhou, H., Zhang, X., and Zhang, Y. 2014a. Expression and clinical significance of colorectal cancer stem cell marker EpCAM(high)/CD44(+) in colorectal cancer. Oncol. Lett. 7(5): 1544-1548.

Liu, G., Yuan, X., Zeng, Z., Tunici, P., Ng, H., Abdulkadir, I. R., et al. 2006. Analysis of gene expression and chemoresistance of CD133+ cancer stem cells in glioblastoma. Mol. Cancer, 5: 67.

Liu, S., Ginestier, C., Ou, S. J., Clouthier, S. G., Patel, S. H., Monville, F., et al. 2011. Breast cancer stem cells are regulated by mesenchymal stem cells through cytokine networks. Cancer Res. 71(2): 614624.

Liu, Z., Dai, W., Jiang, L., and Cheng, Y. 2014b. Over-expression of LGR5 correlates with poor survival of colon cancer in mice as well as in patients. Neoplasma, 61(2): 177-185.

Lomax, M. E., Folkes, L. K., and O'Neill, P. 2013. Biological consequences of radiation-induced DNA damage: relevance to radiotherapy. Clin. Oncol. (R. Coll. Radiol.), 25(10): 578-585.

Lonardo, E., Hermann, P. C., Mueller, M. T., Huber, S., Balic, A., Miranda-Lorenzo, I., et al. 2011. Nodal/Activin signaling drives self-renewal and tumorigenicity of pancreatic cancer stem cells and provides a target for combined drug therapy. Cell Stem Cell, 9(5): 433-446.

Long, B., Wang, L. X., Zheng, F. M., Lai, S. P., Xu, D. R., Hu, Y., et al. 2016. Targeting GLI1 Suppresses Cell Growth and Enhances Chemosensitivity in CD34+ Enriched Acute Myeloid Leukemia Progenitor Cells. Cell Physiol. Biochem. 38(4): 1288-1302.

Long, H., Xiang, T., Qi, W., Huang, J., Chen, J., He, L., et al. 2015. CD133(+) ovarian cancer stem-like cells promote non-stem cancer cell metastasis via CCL5 induced epithelial-mesenchymal transition. Oncotarget, 6(8): 5846-5859.

Longo, R., Torino, F., and Gasparini, G. 2007. Targeted therapy of breast cancer. Curr. Pharm. Des. 13(5): 497-517.

Luo, Y., Nguyen, N., and Fujita, M. 2013. Isolation of human melanoma stem cells using ALDH as a marker. Curr. Protoc. Stem Cell Biol. 26: Unit 3.8.

Mani, S. A., Guo, W., Liao, M. J., Eaton, E. N., Ayyanan, A., Zhou, A. Y., et al. 2008. The epithelialmesenchymal transition generates cells with properties of stem cells. Cell, 133(4): 704-715.

Marjanovic, N. D., Weinberg, R. A., and Chaffer, C. L. 2013. Cell plasticity and heterogeneity in cancer. Clin. Chem. 59(1): 168-179.

Martin, T. A., and Jiang, W. G. 2014. Evaluation of the expression of stem cell markers in human breast cancer reveals a correlation with clinical progression and metastatic disease in ductal carcinoma. Oncol. Rep. 31(1): 262-272.

Matsuda, Y., Naito, Z., Kawahara, K., Nakazawa, N., Korc, M. and Ishiwata, T. 2011. Nestin is a novel target for suppressing pancreatic cancer cell migration, invasion and metastasis. Cancer Biol. Ther. 11(5): 512-523.

Merlos-Suarez, A., Barriga, F. M., Jung, P., Iglesias, M., Cespedes, M. V., Rossell, D., et al. 2011. The intestinal stem cell signature identifies colorectal cancer stem cells and predicts disease relapse. Cell Stem Cell, 8(5): 511-524. 
Miyata, Y., Mitsunari, K., Asai, A., Takehara, K., Mochizuki, Y., and Sakai, H. 2015. Pathological significance and prognostic role of microvessel density, evaluated using CD31, CD34, and CD105 in prostate cancer patients after radical prostatectomy with neoadjuvant therapy. Prostate, 75(1): 8491

Morrison, S. J., and Kimble, J. 2006. Asymmetric and symmetric stem-cell divisions in development and cancer. Nature, 441(7097): 1068-1074.

Muralidharan-Chari, V., Clancy, J. W., Sedgwick, A., and D'Souza-Schorey, C. 2010. Microvesicles: mediators of extracellular communication during cancer progression. J. Cell Sci. 123(Pt 10): 16031611.

Navin, N., Kendall, J., Troge, J., Andrews, P., Rodgers, L., McIndoo, J., et al. 2011. Tumour evolution inferred by single-cell sequencing. Nature, 472(7341): 90-94.

Nik-Zainal, S., Alexandrov, L. B., Wedge, D. C., Van Loo, P., Greenman, C. D., Raine, K., et al. 2012. Mutational processes molding the genomes of 21 breast cancers. Cell, 149(5): 979-993.

Nisticò, P., Di Modugno, F., Spada, S., and Bissell, M. J. 2014. $\beta 1$ and $\beta 4$ integrins: from breast development to clinical practice. Breast Cancer Res. 16(5): 459.

Nowak, J. A., Polak, L., Pasolli, H. A., and Fuchs, E. 2008. Hair Follicle Stem Cells Are Specified and Function in Early Skin Morphogenesis. Cell Stem Cell, 3(1): 33-43.

Nowell, P. C. 1976. The clonal evolution of tumor cell populations. Science, 194(4260): 23-28.

O'Brien, C. A., Pollett, A., Gallinger, S., and Dick, J. E. 2007. A human colon cancer cell capable of initiating tumour growth in immunodeficient mice. Nature, 445(7123): 106-110.

Ohara, Y., Oda, T., Sugano, M., Hashimoto, S., Enomoto, T., Yamada, K., et al. 2013. Histological and prognostic importance of $\mathrm{CD} 44(+) / C D 24(+) / \operatorname{EpCAM}(+)$ expression in clinical pancreatic cancer. Cancer Sci. 104(8): 1127-1134.

Oskarsson, T., Batlle, E., and Massagué, J. 2014. Metastatic Stem Cells: Sources, Niches, and Vital Pathways. Cell Stem Cell, 14(3): 306-321.

Ouyang, L., Shi, Z., Zhao, S., Wang, F. T., Zhou, T. T., Liu, B., et al. 2012. Programmed cell death pathways in cancer: a review of apoptosis, autophagy and programmed necrosis. Cell Prolif. 45(6): 487-498.

Pardal, R., Clarke, M. F., and Morrison, S. J. 2003. Applying the principles of stem-cell biology to cancer. Nat. Rev. Cancer, 3(12): 895-902.

Pastrana, E., Silva-Vargas, V., and Doetsch, F. 2011. Eyes Wide Open: A Critical Review of SphereFormation as an Assay for Stem Cells. Cell Stem Cell, 8(5): 486-498.

Pearl, L. H., Schierz, A. C., Ward, S. E., Al-Lazikani, B., and Pearl, F. M. 2015. Therapeutic opportunities within the DNA damage response. Nat. Rev. Cancer, 15(3): 166-180. 
1101

1102

1103

1104

1105

1106

1107

1108

1109

1110

1111

1112

1113

1114

1115

1116

1117

1118

1119

1120

1121

1122

1123

1124

1125

1126

1127

1128

1129

1130

1131

1132

1133

1134

1135

1136

1137

1138

1139

1140

1141

1142

1143

1144

1145

1146

1147

1148

1149

1150

Peiris-Pages, M., Sotgia, F., and Lisanti, M. P. 2015. Chemotherapy induces the cancer-associated fibroblast phenotype, activating paracrine Hedgehog-GLI signalling in breast cancer cells. Oncotarget, 6(13): 10728-10745.

Pelosi, G., Barisella, M., Pasini, F., Leon, M. E., Veronesi, G., Spaggiari, L., et al. 2004. CD117 immunoreactivity in stage I adenocarcinoma and squamous cell carcinoma of the lung: relevance to prognosis in a subset of adenocarcinoma patients. Mod. Pathol. 17(6): 711-721.

Phillips, T. M., McBride, W. H., and Pajonk, F. 2006. The response of CD24(-/low)/CD44+ breast cancer-initiating cells to radiation. J. Natl. Cancer Inst. 98(24): 1777-1785.

Pinc, A., Somasundaram, R., Wagner, C., Hormann, M., Karanikas, G., Jalili, A., et al. 2012. Targeting CD20 in melanoma patients at high risk of disease recurrence. Mol. Ther. 20(5): 1056-1062.

Polyak, K. 2011. Heterogeneity in breast cancer. J. Clin. Invest. 121(10): 3786-3788.

Quintana, E., Shackleton, M., Foster, H. R., Fullen, D. R., Sabel, M. S., Johnson, T. M., et al. 2010. Phenotypic heterogeneity among tumorigenic melanoma cells from patients that is reversible and not hierarchically organized. Cancer Cell, 18(5): 510-523.

Quintana, E., Shackleton, M., Sabel, M. S., Fullen, D. R., Johnson, T. M., and Morrison, S. J. 2008. Efficient tumour formation by single human melanoma cells. Nature, 456(7222): 593-598.

Rajaram, R. D., Buric, D., Caikovski, M., Ayyanan, A., Rougemont, J., Shan, J., et al. 2015. Progesterone and Wnt4 control mammary stem cells via myoepithelial crosstalk. EMBO J. 34(5): 641652.

Ren, F., Sheng, W. Q., and Du, X. 2013. CD133: a cancer stem cells marker, is used in colorectal cancers. World J. Gastroenterol. 19(17): 2603-2611.

Reya, T., Morrison, S. J., Clarke, M. F., and Weissman, I. L. 2001. Stem cells, cancer, and cancer stem cells. Nature, 414(6859): 105-111.

Ricardo, S., Vieira, A. F., Gerhard, R., Leitao, D., Pinto, R., Cameselle-Teijeiro, J. F., et al. 2011. Breast cancer stem cell markers CD44, CD24 and ALDH1: expression distribution within intrinsic molecular subtype. J. Clin. Pathol. 64(11): 937-946.

Ricci-Vitiani, L., Lombardi, D. G., Pilozzi, E., Biffoni, M., Todaro, M., Peschle, C., et al. 2007. Identification and expansion of human colon-cancer-initiating cells. Nature, 445(7123): 111-115.

Roesch, A., Fukunaga-Kalabis, M., Schmidt, E. C., Zabierowski, S. E., Brafford, P. A., Vultur, A., et al. 2010. A temporarily distinct subpopulation of slow-cycling melanoma cells is required for continuous tumor growth. Cell, 141(4): 583-594.

Roug, A. S., Larsen, H. O., Nederby, L., Just, T., Brown, G., Nyvold, C. G., et al. 2014. hMICL and CD123 in combination with a CD45/CD34/CD117 backbone - a universal marker combination for the detection of minimal residual disease in acute myeloid leukaemia. Br. J. Haematol. 164(2): 212-222.

Ryu, B. K., Lee, M. G., Chi, S. G., Kim, Y. W., and Park, J. H. 2001. Increased expression of cFLIP(L) in colonic adenocarcinoma. J. Pathol. 194(1): 15-19. 
1151

1152

1153

1154

1155

1156

1157

1158

1159

1160

1161

1162

1163

1164

1165

1166

1167

1168

1169

1170

1171

1172

1173

1174

1175

1176

1177

1178

1179

1180

1181

1182

1183

1184

1185

1186

1187

1188

1189

1190

1191

1192

1193

1194

1195

1196

1197

1198

1199

1200
Sabet, M. N., Rakhshan, A., Erfani, E., and Madjd, Z. 2014. Co-expression of putative cancer stem cell markers, CD133 and Nestin, in skin tumors. Asian Pac. J. Cancer Prev. 15(19): 8161-8169.

Sacks, J. D., and Barbolina, M. V. 2015. Expression and Function of CD44 in Epithelial Ovarian Carcinoma. Biomolecules, 5(4): 3051-3066.

Sampieri, K., and Fodde, R. 2012. Cancer stem cells and metastasis. Semin. Cancer Biol. 22(3): 187193.

Sarah, P., and David, M. 2008. Mechanisms of anticancer drugs. In Scott-Brown's Otorhinolaryngology: Head and Neck Surgery. Edited by S.Payne and D.Miles. CRC Press. pp. 34-46.

Saudy, N. S., Fawzy, I. M., Azmy, E., Goda, E. F., Eneen, A., and Abdul Salam, E. M. 2014. BMI1 gene expression in myeloid leukemias and its impact on prognosis. Blood Cells Mol. Dis. 53(4): 194-198.

Schatton, T., Murphy, G. F., Frank, N. Y., Yamaura, K., Waaga-Gasser, A. M., Gasser, M., et al. 2008. Identification of cells initiating human melanomas. Nature, 451(7176): 345-349.

Scheel, C., Eaton, E. N., Li, S. H., Chaffer, C. L., Reinhardt, F., Kah, K. J., et al. 2011. Paracrine and autocrine signals induce and maintain mesenchymal and stem cell states in the breast. Cell, 145(6): 926-940.

Schepers, A. G., Snippert, H. J., Stange, D. E., van den Born, M., van Es, J. H., van de Wetering, M., et al. 2012. Lineage tracing reveals Lgr5+ stem cell activity in mouse intestinal adenomas. Science, 337(6095): 730-735.

Schmitt, C. A., Fridman, J. S., Yang, M., Baranov, E., Hoffman, R. M., and Lowe, S. W. 2002. Dissecting p53 tumor suppressor functions in vivo. Cancer Cell, 1(3): 289-298.

Schuh, A., Becq, J., Humphray, S., Alexa, A., Burns, A., Clifford, R., et al. 2012. Monitoring chronic lymphocytic leukemia progression by whole genome sequencing reveals heterogeneous clonal evolution patterns. Blood, 120(20): 4191-4196.

Schwitalla, S., Fingerle, A. A., Cammareri, P., Nebelsiek, T., Goktuna, S. I., Ziegler, P. K., et al. 2013. Intestinal tumorigenesis initiated by dedifferentiation and acquisition of stem-cell-like properties. Cell, 152(1-2): 25-38.

Seigel, G. M., and Campbell, L. M. 2004. High-throughput microtiter assay for Hoechst 33342 dye uptake. Cytotechnology, 45(3): 155-160.

Sell, S. 2004. Stem cell origin of cancer and differentiation therapy. Crit. Rev. Oncol. Hematol. 51(1): $1-28$.

Shackleton, M., Quintana, E., Fearon, E. R., and Morrison, S. J. 2009. Heterogeneity in cancer: cancer stem cells versus clonal evolution. Cell, 138(5): 822-829.

Shafaei, S., Sharbatdaran, M., Kamrani, G., and Khafri, S. 2013. The association between CD166 detection rate and clinicopathologic parameters of patients with colorectal cancer. Caspian J. Intern. Med. 4(4): 768-772. 
Shah, S. P., Roth, A., Goya, R., Oloumi, A., Ha, G., Zhao, Y., et al. 2012. The clonal and mutational evolution spectrum of primary triple-negative breast cancers. Nature, 486(7403): 395-399.

Sharma, S. V., Lee, D. Y., Li, B., Quinlan, M. P., Takahashi, F., Maheswaran, S., et al. 2010. A chromatin-mediated reversible drug-tolerant state in cancer cell subpopulations. Cell, 141(1): 69-80.

Shiozawa, Y., Nie, B., Pienta, K. J., Morgan, T. M., and Taichman, R. S. 2013. Cancer stem cells and their role in metastasis. Pharmacol. Ther. 138(2): 285-293.

Singec, I., Knoth, R., Meyer, R. P., Maciaczyk, J., Volk, B., Nikkhah, G., et al. 2006. Defining the actual sensitivity and specificity of the neurosphere assay in stem cell biology. Nat. Methods, 3(10): 801806.

Singh, J. K., Simões, B. M., Howell, S. J., Farnie, G., and Clarke, R. B. 2013. Recent advances reveal IL-8 signaling as a potential key to targeting breast cancer stem cells. Breast Cancer Res. 15(4): 210-210.

Snippert, H. J., van der Flier, L. G., Sato, T., van Es, J. H., van den Born, M., Kroon-Veenboer, C., et al. 2010. Intestinal crypt homeostasis results from neutral competition between symmetrically dividing Lgr5 stem cells. Cell, 143(1): 134-144.

Tagscherer, K. E., Fassl, A., Campos, B., Farhadi, M., Kraemer, A., Bock, B. C., et al. 2008. Apoptosisbased treatment of glioblastomas with ABT-737, a novel small molecule inhibitor of Bcl-2 family proteins. Oncogene, 27(52): 6646-6656.

Tan, Y., Chen, B., Xu, W., Zhao, W., and Wu, J. 2014. Clinicopathological significance of CD133 in lung cancer: A meta-analysis. Mol. Clin. Oncol. 2(1): 111-115.

Tanei, T., Morimoto, K., Shimazu, K., Kim, S. J., Tanji, Y., Taguchi, T., et al. 2009. Association of breast cancer stem cells identified by aldehyde dehydrogenase 1 expression with resistance to sequential Paclitaxel and epirubicin-based chemotherapy for breast cancers. Clin. Cancer Res. 15(12): 42344241.

Tang, K. H., Ma, S., Lee, T. K., Chan, Y. P., Kwan, P. S., Tong, C. M., et al. 2012. CD133(+) liver tumorinitiating cells promote tumor angiogenesis, growth, and self-renewal through neurotensin/interleukin-8/CXCL1 signaling. Hepatology, 55(3): 807-820.

Testa, U., Pelosi, E., and Frankel, A. 2014. CD 123 is a membrane biomarker and a therapeutic target in hematologic malignancies. Biomark Res. 2(1): 4.

Todaro, M., Alea, M. P., Di Stefano, A. B., Cammareri, P., Vermeulen, L., lovino, F., et al. 2007. Colon cancer stem cells dictate tumor growth and resist cell death by production of interleukin-4. Cell Stem Cell, 1(4): 389-402.

Todaro, M., Zerilli, M., Ricci-Vitiani, L., Bini, M., Perez Alea, M., Maria Florena, A., et al. 2006. Autocrine production of interleukin-4 and interleukin-10 is required for survival and growth of thyroid cancer cells. Cancer Res. 66(3): 1491-1499.

Touil, Y., Igoudjil, W., Corvaisier, M., Dessein, A. F., Vandomme, J., Monte, D., et al. 2014. Colon cancer cells escape 5FU chemotherapy-induced cell death by entering stemness and quiescence associated with the c-Yes/YAP axis. Clin. Cancer Res. 20(4): 837-846. 
Trerotola, M., Jernigan, D. L., Liu, Q., Siddiqui, J., Fatatis, A., and Languino, L. R. 2013. Trop-2 promotes prostate cancer metastasis by modulating beta(1) integrin functions. Cancer Res. 73(10): 3155-3167.

Trerotola, M., Li, J., Alberti, S., and Languino, L. R. 2012. Trop-2 inhibits prostate cancer cell adhesion to fibronectin through the beta1 integrin-RACK1 axis. J. Cell Physiol. 227(11): 3670-3677.

van Rhenen, A., Feller, N., Kelder, A., Westra, A. H., Rombouts, E., Zweegman, S., et al. 2005. High stem cell frequency in acute myeloid leukemia at diagnosis predicts high minimal residual disease and poor survival. Clin. Cancer Res. 11(18): 6520-6527.

Vander Griend, D. J., Karthaus, W. L., Dalrymple, S., Meeker, A., DeMarzo, A. M., and Isaacs, J. T. 2008. The role of CD133 in normal human prostate stem cells and malignant cancer-initiating cells. Cancer Res. 68(23): 9703-9711.

Venere, M., Hamerlik, P., Wu, Q., Rasmussen, R. D., Song, L. A., Vasanji, A., et al. 2014. Therapeutic targeting of constitutive PARP activation compromises stem cell phenotype and survival of glioblastoma-initiating cells. Cell Death Differ. 21(2): 258-269.

Venkatesha, V. A., Parsels, L. A., Parsels, J. D., Zhao, L., Zabludoff, S. D., Simeone, D. M., et al. 2012. Sensitization of pancreatic cancer stem cells to gemcitabine by Chk1 inhibition. Neoplasia, 14(6): 519-525.

Vidal, S. J., Rodriguez-Bravo, V., Galsky, M., Cordon-Cardo, C., and Domingo-Domenech, J. 2014. Targeting cancer stem cells to suppress acquired chemotherapy resistance. Oncogene, 33(36): 44514463.

Vignot, S., Frampton, G. M., Soria, J. C., Yelensky, R., Commo, F., Brambilla, C., et al. 2013. Nextgeneration sequencing reveals high concordance of recurrent somatic alterations between primary tumor and metastases from patients with non-small-cell lung cancer. J. Clin. Oncol. 31(17): 21672172.

Visvader, J.E., and Lindeman, G. J. 2012. Cancer Stem Cells: Current Status and Evolving Complexities. Cell Stem Cell, 10(6): 717-728.

Waddell, N., Pajic, M., Patch, A.-M., Chang, D. K., Kassahn, K. S., Bailey, P., et al. 2015. Whole genomes redefine the mutational landscape of pancreatic cancer. Nature, 518(7540): 495-501.

Wakita, S., Yamaguchi, H., Miyake, K., Mitamura, Y., Kosaka, F., Dan, K., et al. 2011. Importance of ckit mutation detection method sensitivity in prognostic analyses of $t(8 ; 21)(q 22 ; q 22)$ acute myeloid leukemia. Leukemia, 25(9): 1423-1432.

Walter, M. J., Shen, D., Ding, L., Shao, J., Koboldt, D. C., Chen, K., et al. 2012. Clonal Architecture of Secondary Acute Myeloid Leukemia. N. Engl. J. Med. 366(12): 1090-1098.

Wang, B. B., Li, Z. J., Zhang, F. F., Hou, H. T., Yu, J. K., and Li, F. 2016. Clinical significance of stem cell marker CD133 expression in colorectal cancer. Histol. Histopathol. 31(3): 299-306.

Wang, F., Xue, X., Wei, J., An, Y., Yao, J., Cai, H., et al. 2010. hsa-miR-520h downregulates ABCG2 in pancreatic cancer cells to inhibit migration, invasion, and side populations. Br. J. Cancer, 103(4): 567574. 
Wang, X., Liu, Y., Zhou, K., Zhang, G., Wang, F., and Ren, J. 2015. Isolation and characterization of CD105(+)/CD90(+) subpopulation in breast cancer MDA-MB-231 cell line. Int. J. Clin. Exp. Pathol. 8(5): 5105-5112.

Wang, X. K., To, K. K., Huang, L. Y., Xu, J. H., Yang, K., Wang, F., et al. 2014. Afatinib circumvents multidrug resistance via dually inhibiting ATP binding cassette subfamily $\mathrm{G}$ member 2 in vitro and in vivo. Oncotarget, 5(23): 11971-11985.

Wang, Z., and Sun, Y. 2010. Targeting p53 for Novel Anticancer Therapy. Transl. Oncol. 3(1): 1-12.

Wei, H. J., Yin, T., Zhu, Z., Shi, P. F., Tian, Y., and Wang, C. Y. 2011. Expression of CD44, CD24 and ESA in pancreatic adenocarcinoma cell lines varies with local microenvironment. Hepatobiliary Pancreat. Dis. Int. 10(4): 428-434.

Xu, X., Hou, Y., Yin, X., Bao, L., Tang, A., Song, L., et al. 2012. Single-cell exome sequencing reveals single-nucleotide mutation characteristics of a kidney tumor. Cell, 148(5): 886-895.

Yan, X., Luo, H., Zhou, X., Zhu, B., Wang, Y., and Bian, X. 2013. Identification of CD90 as a marker for lung cancer stem cells in A549 and H446 cell lines. Oncol. Rep. 30(6): 2733-2740.

Yang, L., Tang, H., Kong, Y., Xie, X., Chen, J., Song, C., et al. 2015. LGR5 Promotes Breast Cancer Progression and Maintains Stem-Like Cells Through Activation of Wnt/beta-Catenin Signaling. Stem Cells, 33(10): 2913-2924.

Yang, Z. F., Ho, D. W., Ng, M. N., Lau, C. K., Yu, W. C., Ngai, P., et al. 2008. Significance of CD90+ cancer stem cells in human liver cancer. Cancer Cell, 13(2): 153-166.

Ye, J., Wu, D., Wu, P., Chen, Z., and Huang, J. 2014. The cancer stem cell niche: cross talk between cancer stem cells and their microenvironment. Tumour Biol. 35(5): 3945-3951.

Yeh, S. C., Wang, P. Y., Lou, Y. W., Khoo, K. H., Hsiao, M., Hsu, T. L., et al. 2016. Glycolipid GD3 and GD3 synthase are key drivers for glioblastoma stem cells and tumorigenicity. Proc. Natl. Acad. Sci. U.S.A. 113(20): 5592-5597.

Yu, C., Yao, Z., Dai, J., Zhang, H., Escara-Wilke, J., Zhang, X., et al. 2011. ALDH activity indicates increased tumorigenic cells, but not cancer stem cells, in prostate cancer cell lines. In Vivo, 25(1): 6976.

Zhang, D., Park, D., Zhong, Y., Lu, Y., Rycaj, K., Gong, S., et al. 2016. Stem cell and neurogenic geneexpression profiles link prostate basal cells to aggressive prostate cancer. Nature Communications, 7: 10798.

Zhang, H., Wu, S., and Xing, D. 2011. YAP accelerates Abeta(25-35)-induced apoptosis through upregulation of Bax expression by interaction with p73. Apoptosis, 16(8): 808-821.

Zhang, M., Song, T., Yang, L., Chen, R., Wu, L., Yang, Z., et al. 2008. Nestin and CD133: valuable stem cell-specific markers for determining clinical outcome of glioma patients. J. Exp. Clin. Cancer Res. 27: 85.

Zhang, X., Yuan, X., Shi, H., Wu, L., Qian, H., and Xu, W. 2015. Exosomes in cancer: small particle, big player. J. Hematol. Oncol. 8: 83. 
1353 Zobalova, R., McDermott, L., Stantic, M., Prokopova, K., Dong, L.-F. and Neuzil, J. 2008a. CD1331354 positive cells are resistant to TRAIL due to up-regulation of FLIP. Biochem. Biophys. Res. Commun. 1355 373(4): 567-571.

1356

1357

1358

1359

1360

1361

1362

1363

1364

Zobalova, R., Stantic, M., Prokopova, K., Dong, L. F., and Neuzil, J. 2008b. Cancer cells with high expression of CD133 exert FLIP upregulation and resistance to TRAIL-induced apoptosis. Biofactors, 34(3): 231-235.

Zöller, M. 2015. CD44, Hyaluronan, the Hematopoietic Stem Cell, and Leukemia-Initiating Cells. Front. Immunol. 6: 235.

1365 


\section{Figure legend}

1367

1368 Figure 1. Acquisition of therapy resistance in CSCs occurs through a number of mechanisms.

1369 a) Schematic showing how chemo- and radio- therapy affects some of the known components

1370 of the intrinsic apoptotic pathway that leads to programmed cell death in tumor cells, b)

1371 Active DNA repair combines with defective apoptotic pathways and increased pro-survival

1372 signaling in chemoresistant CSCs, c) Multidrug resistance (MDR) is a major problem that 1373 prevents the successful eradication of cancer cells. A common mechanism is the over 1374 expression of ATP-binding cassette (ABC) efflux transporters in cancer cells such as P1375 glycoprotein (P-gp/ABCB1), multidrug resistance-associated protein1 (MRP1/ABCC1) and 1376 breast cancer resistance protein (BCRP/ABCG2) that limit the cell's exposure to anticancer 1377 drugs. d) Induction of quiescence is another means by which CSCs protect themselves from 1378 the deleterious effects of chemo- and radio- therapy. Exposure to 5-Fluorouracil activates c1379 Yes tyrosine kinase in chemoresistant CSCs. Phosphorylation of c-Yes leads to dissociation 1380 of the YAP/ c-Yes complex and translocation of nuclear Yap to the cytoplasm. Disruption of 1381 the YAP/ c-Yes complex prevents cell cycle progression and is a possible means by which 1382 CSCs induce quiescence. Note that circles and squares represent active and inactive forms of 1383 proteins respectively. 


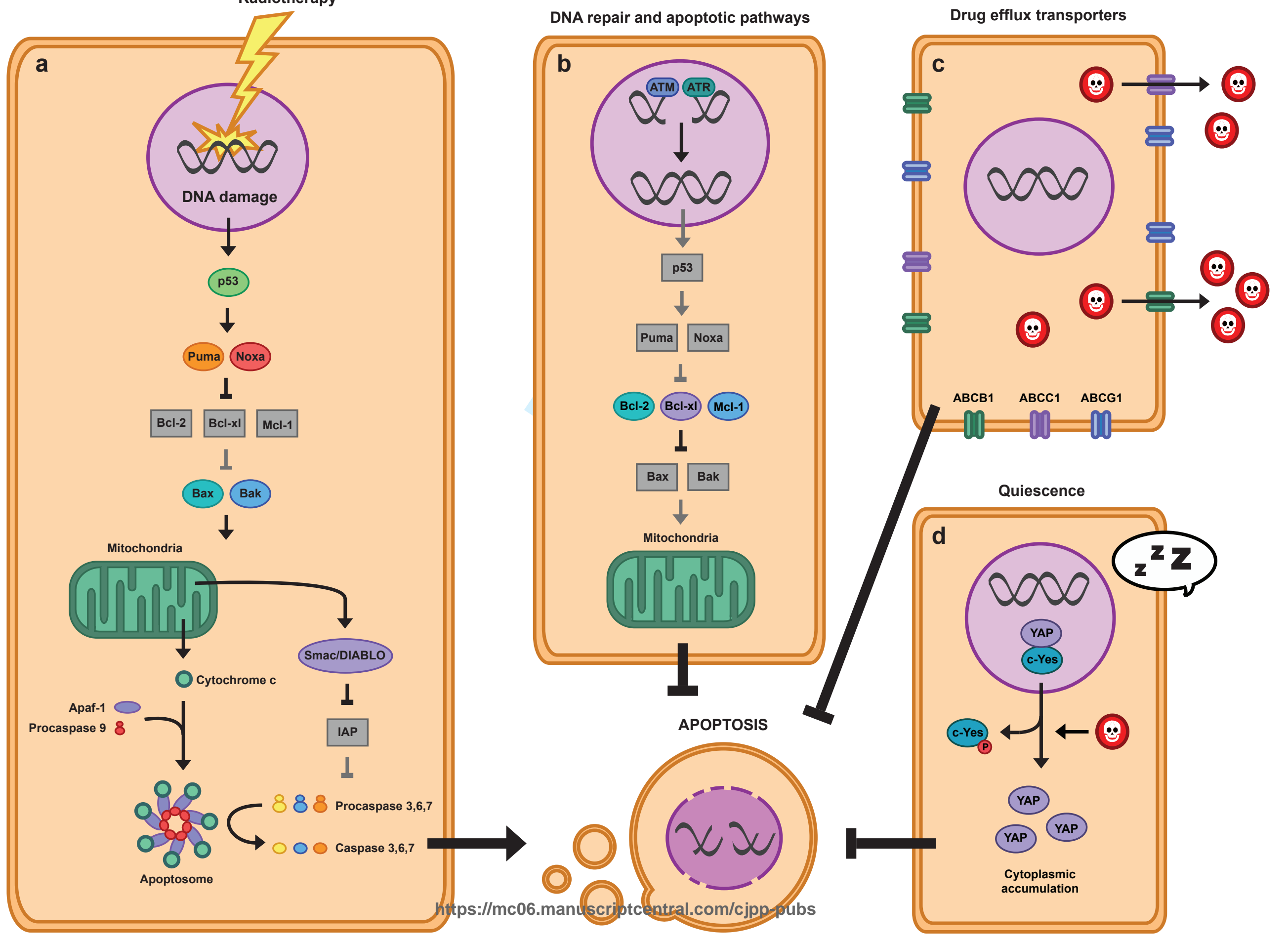

